
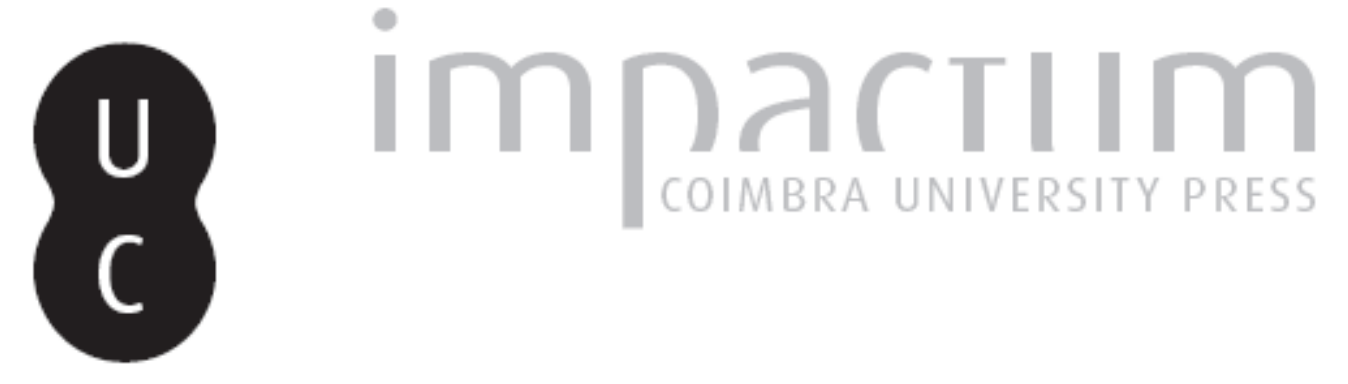

\title{
Três bibliotecas particulares na Coimbra de trezentos: em torno das elites e das culturas urbanas medievais
}

Autor(es): $\quad$ Gomes, Saul António

Publicado por: Imprensa da Universidade de Coimbra

URL persistente:

URI:http://hdl.handle.net/10316.2/43714

DOI:

DOI:https://doi.org/10.14195/2183-8925_24_1

Accessed : $\quad$ 26-Apr-2023 00:53:28

A navegação consulta e descarregamento dos títulos inseridos nas Bibliotecas Digitais UC Digitalis, UC Pombalina e UC Impactum, pressupõem a aceitação plena e sem reservas dos Termos e Condições de Uso destas Bibliotecas Digitais, disponíveis em https://digitalis.uc.pt/pt-pt/termos.

Conforme exposto nos referidos Termos e Condições de Uso, o descarregamento de títulos de acesso restrito requer uma licença válida de autorização devendo o utilizador aceder ao(s) documento(s) a partir de um endereço de IP da instituição detentora da supramencionada licença.

Ao utilizador é apenas permitido o descarregamento para uso pessoal, pelo que o emprego do(s) título(s) descarregado(s) para outro fim, designadamente comercial, carece de autorização do respetivo autor ou editor da obra.

Na medida em que todas as obras da UC Digitalis se encontram protegidas pelo Código do Direito de Autor e Direitos Conexos e demais legislação aplicável, toda a cópia, parcial ou total, deste documento, nos casos em que é legalmente admitida, deverá conter ou fazer-se acompanhar por este aviso.

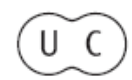



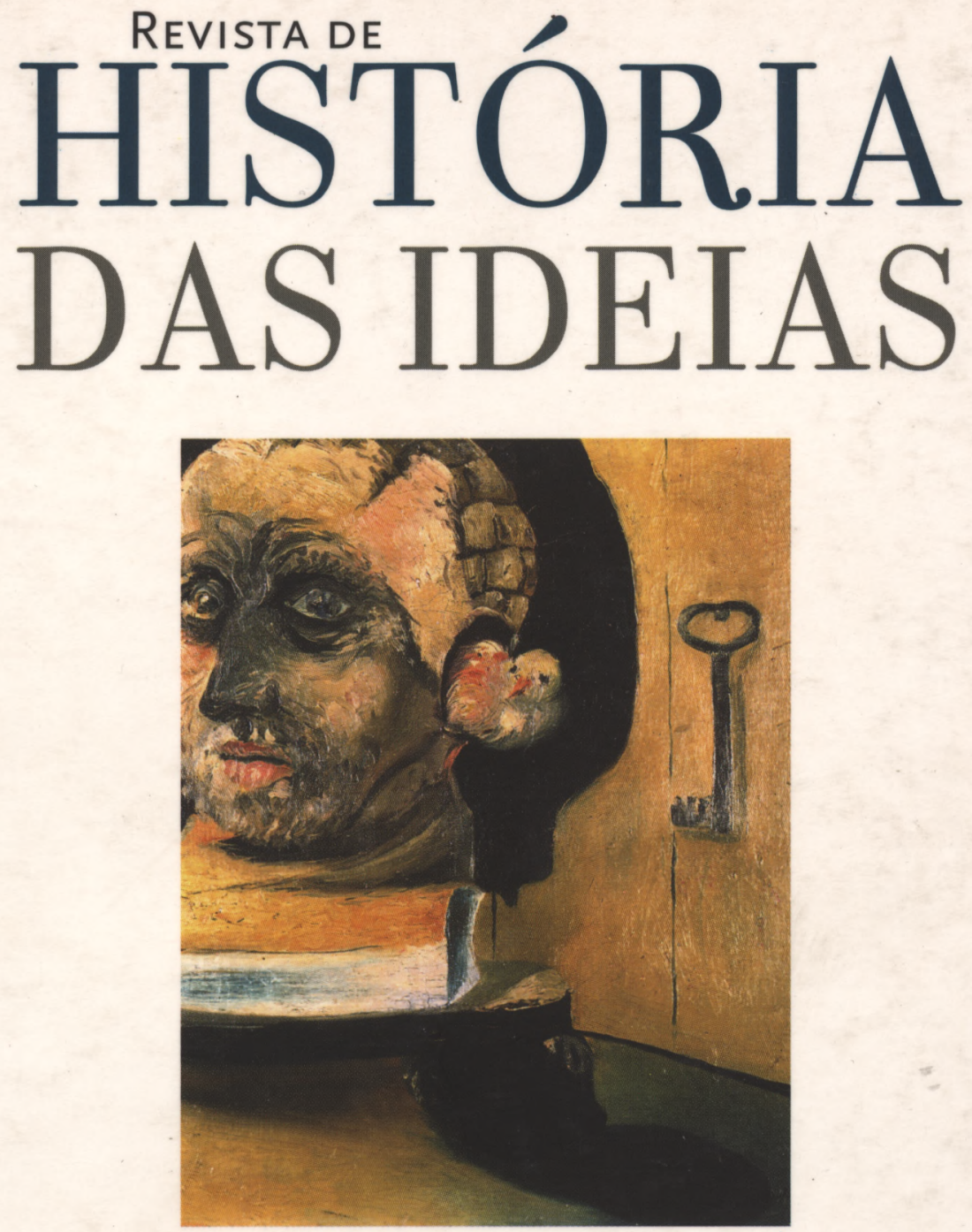

OS INTELECTUAIS E OS PODERES

Volume 24, 2003

INSTITUTO DE HISTÓRIA E TEORIA DAS IDEIAS

Faculdade de Letras da Universidade de Coimbra 


\section{TRÊS BIBLIOTECAS PARTICULARES NA COIMBRA DE TREZENTOS Em torno das elites e das culturas urbanas medievais}

1. Toda a cidade, muito em especial a civitas medieval, é um universo memorial de práticas e de manifestações culturais múltiplas. As suas superfícies, pautadas pela persistência de torres, muralhas, palácios e igrejas, são paisagens geométricas de topografias locais que reflectem a capacidade definidora dos poderes que determinaram a fundação de cada pólo citadino, tanto quanto elucidam a gestão da evolução histórica, em que se contemplam progressos e declínios, da respectiva fisionomia urbanística ${ }^{(1)}$.

Mas uma urbe não é, naturalmente, apenas um fenómeno físico ou espacial. Ela é, por excelência, em particular nos séculos medievos, um complexo sistema de linguagens, de culturas e de mentalidades plurais, dentre as quais sobressai uma identidade comunitária produtora de discursos sociais integradores - bem aferíveis na sempre prodigiosa legislação de produção local - e, também, diferenciadores.

* Faculdade de Letras da Universidade de Coimbra. Centro de História da Sociedade e da Cultura da Universidade de Coimbra e colaborador do Centro de Estudos de História Religiosa da Universidade Católica Portuguesa.

(1) Sobre a cidade medieval enquanto território de práticas culturais e de criação de memória social, vide Anna Imelde Galletti, "Les Langages de la Culture Urbaine $\left(\mathrm{XII}-\mathrm{XV} \mathrm{V}^{\mathrm{e}}\right.$ siècle)", in Cultures Italiennes (XII $-\mathrm{XV}^{e}$ siècle), (Dir. Isabelle Heullant-Donat), Paris, Cerf, 2000, pp. 17-51. 
Um belo quadro pictórico de Ambrogio Lorenzetti, observável na Pinacoteca de Siena, apresenta-nos uma cidade junto ao mar. Uma cidade sem nome, insituada, mas cidade do imaginário dos contemporâneos do afamado artista trecentista sienense que, intérprete de sensibilidades comuns, a pinta nos seus elementos identificadores principais: no cimo da colina, o recinto acastelado que recorda a urbe quando castrum embrionário; depois, panos de muralhas ritmados de merlões e ameias envolvem todas as casas, apenhadas no entorno de belas igrejas com os seus campanários, algumas possuindo altíssimas torres paçãs, tais mirantes onde se mostra a riqueza de cada proprietário, dos quais, decerto, fosse a cidade autêntica, se desfrutaria das mais belas vistas e paisagens. Uma enorme porta fortificada permite a comunicação com o terreiro envolvente, os despovoados suburbia, e conduz à orla marinha da qual se aproximam algumas poucas naves de velas enfunadas.

A cidade é, aqui, uma composição estética. Porque, nesse distante século de Trezentos, a cidade merecia já a consideração e a dignidade de se ver representada, no cavalete de um artista reconhecido, como se de uma personagem intrigante e simbólica se tratasse. Desde então, na verdade, a cidade e os seus mobiliários tornam-se presenças habituais no mapa da produção artística europeia ocidental. Pintores e escultores, artistas ou artífices, são gentes essencialmente urbanas e servem sensibilidades de consumidores igualmente marcados pelo prisma das linguagens citadinas.

Noutros lugares urbanos, por exemplo, como sucedia em Lisboa já no último terço de Duzentos, para os quais não temos, infelizmente, pinturas medievas que no-los representem, os selos municipais, ícones de belo recorte ideológico-comunitário, mostram, numa das suas faces, a própria cidade, não através de uma alegoria mitológica, mas antes enquanto composição cartográfica em que podemos visitar o espaço urbano entrevendo todo o perímetro amuralhado e as igrejas e/ou monumentos que marcam a planimetria do espaço representado ${ }^{(2)}$.

A cidade é, assim, na paleta de um pintor medieval ou no cinzel de um sigillator, um espaço físico e mental, uma imagem que os seus habitantes gostavam de contemplar, de muralhas e de igrejas, símbolos

(2) Veja-se uma reprodução deste conhecido selo na obra de Avelino de Jesus da Costa, Album de Paleografia e Diplomática Portuguesas. Estampas, Coimbra, Faculdade de Letras da Universidade de Coimbra, 6 ed., 1997, Estampa n. ${ }^{\circ} 309$. 
monumentais de segurança e da paz, valores caros ao imaginário cristão ${ }^{(3)}$. Imagem de cidade, naturalmente, que os visitantes podem guardar na memória como uma composição ideal carregada de cores, de formas geométricas e de sentidos culturais múltiplos que lhe advêm, naturalmente, das suas características urbanas e económicas, dos seus tecidos sociais, dos seus sistemas de governo e das suas dinâmicas políticas e intelectuais.

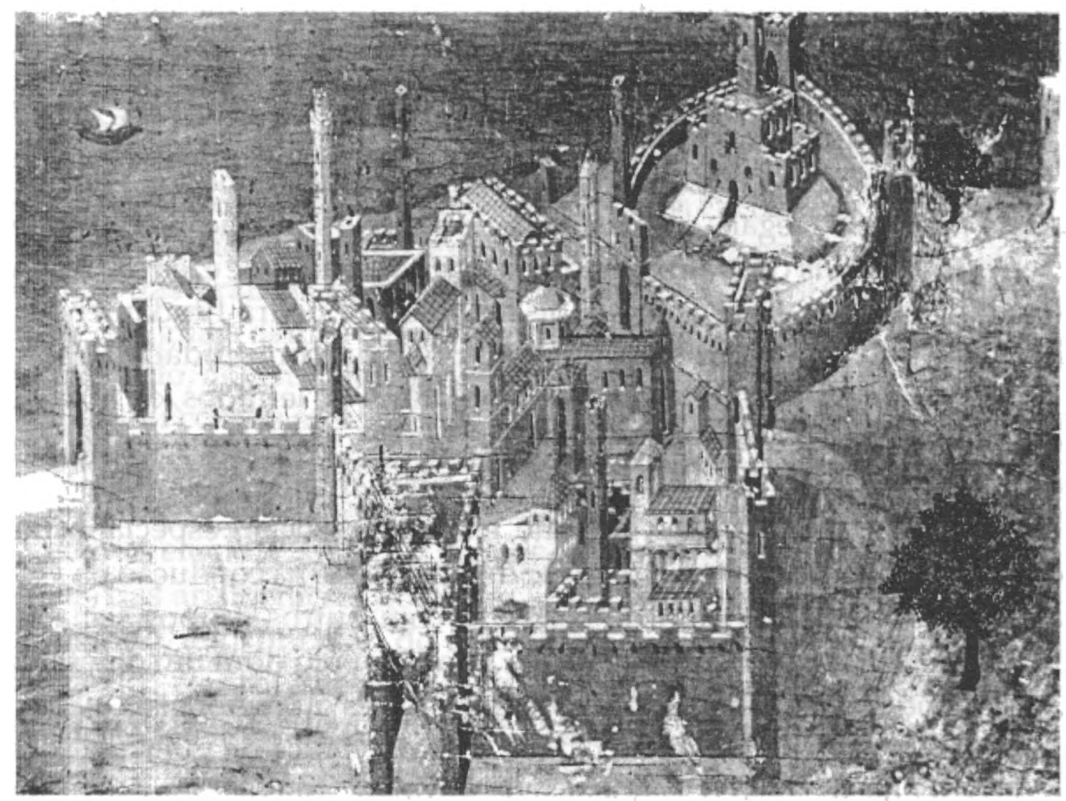

Cidade junto ao Mar, de Ambrogio Lorenzetti

(Pinacoteca de Siena). Séc. XIV.

Porque a cidade medieva, com a sua generosa capacidade assimiladora de grupos étnico-sociais exógenos ou com a sua determinada obstinação de rejeitar e expulsar elementos desintegrados, propõe-se como um território de aculturações diversificadas dentro do qual se gera e repete uma capacidade de sobrevivência inter-geracional de expressões culturais, de costumes, de linguagens e de representações ideológicas.

(3) André Malraux, "L'immaginario cristiano", I regni d'Occidente (Dir. François Avril, Xavier Barral I Altet e Danielle Gaborit-Chopin), Milão, Rizzoli, 1984, pp. 337-346. 
Ultrapassada a crise urbana dos tempos alto-medievais, especialmente após o ano Mil, as cidades recuperam a vocação, o prestígio e a influência política propostos no legado civilizacional helénico ${ }^{(4)}$. Elas tornaram-se, numa dinâmica sempre crescente, com ou sem patrocínios senhoriais, em comunidades urbanas geridas por códigos jurídicos escritos - e a escrita, latina e/ou vernacular, sublinhemo-lo, é um elemento fundamental na afirmação das identidades urbanas - cujas matrizes eram zelosamente guardadas nos arquivos locais e cuidadosamente interpretadas e aplicadas por elites sociais que controlavam o poder concelhio e que tinham, não raramente, ao seu serviço, ao serviço do concilium entenda-se, grupos de amanuenses eruditos e letrados.

A cidade medieva não era apenas, naturalmente, monopólio de uma cultura jurídica ou legal - cuja visibilidade se pode simbolicamente remeter ao monumentum centralizador da prática da justiça que é, em território português, o pelourinho, coluna de referência e pedra fundamental à afirmação pública da identidade simbólica da comunidade urbana - servida, como referimos, por um corpo plural de letrados, de juristas, de notários, de escrivães de ofício e de zelosos servidores da Lei nos domínios coercitivos do civil, do crime, do policiamento urbano e mesmo dos costumes religiosos. Obviamente, estas elites sociais especializadas no saber jurídico ocupavam um lugar determinante na condução da vida da civitas, mas elas tinham de conviver com outros grupos sociais e profissionais cujas culturas passavam também pelo domínio da escrita e, sobremodo, pelo controle dos mercados locais ou regionais ${ }^{(5)}$.

Excepcionalmente, ainda, a cidade torna-se praça de guerra e sofre dolorosamente as suas consequências destrutivas. Mas a linha estrutural prosseguida é a da segurança e a da paz urbanas, obrigando a avultados investimentos na edificação e manutenção de estruturas defensivas, bem como na satisfação de pedidos e de impostos para custeamento de exércitos e dos seus condestáveis. Noutras circunstâncias, a cidade revela o seu enorme apreço pelas comemorações cívicas e religiosas, comprometendo-se à celebração de um calendário festivo que tem determinados

(4) Vide Henri Focillon, O Ano Mil, Lisboa, Estampa, 1977, p. 73 ss.; Idem, Arte do Ocidente. A Idade Média Românica e Gótica, Lisboa, Estampa, 1980, pp. 34-56.

(5) Cf. Jack Goody, A lógica da escrita e a organização da sociedade, Lisboa, Edições 70, 1987, p. 107 ss. 
momentos altos, como se demonstra, por exemplo, nas eloquentes procissões públicas do Corpo de Deus ou, numa vertente mais cívica, nas entradas régias ou principescas ${ }^{(6)}$.

Mas a cidade medieva afirmou-se superiormente - reflectindo, aqui, algo das ideias de $\mathrm{H}$. Pirenne acerca da razão originária da urbe - como espaço de mercado ou de comércio e, também, especialmente nos seus subúrbios, como sector de produção artesanal e manufactureira.

A estas funcionalidades correspondem, necessariamente, grupos sociais com linguagens e práticas culturais diferenciadas entre si. Nos espaços de mercado, obviamente, encontramos o território privilegiado de manifestação das culturas mercantis, culturas de gestão e de negócio, mas também, naturalmente, de gentes marcadas por códigos éticos e por mentalidades próprias, seja no campo da devoção religiosa, seja nos domínios da vida familiar, das práticas de alfabetização ou dos comportamentos, obviamente desiguais dentro desse próprio grupo mercantil, no que respeita, por exemplo, ao usufruto de bens culturais e estéticos ${ }^{(7)}$.

E, de par com os mercadores, o mundo artesanal, aferido por códigos sóciotécnicos uniformizadores de qualidade de trabalho e de produção, bem como por uma rigorosa apologia de valores hierárquicos. Como deveremos elucidar, ainda, os lugares sociais das culturas patriciais dominantes, das aristocracias do poder local, dos senhorios principescos, e, sobremodo, a justificação do foro apartado que caracterizava o grupo eclesiástico-clerical, sempre omnipresente na cidade, tanto quanto, por vezes, os bairros de estudantes e mestres universitários.

Para, finalmente, nas margens da vivência urbana, chegarmos às sociabilidades e mentalidades negativas ${ }^{(8)}$, excluídas ou refractárias,

(6) Vide Ana Maria Alves, As Entradas Régias Portuguesas, Lisboa, Livros Horizonte, s.d.; Maria João Branco Marques da Silva, "A Procissão na Cidade: reflexões em torno da festa do Corpo de Deus na Idade Média Portuguesa", in Actas de "A Cidade". Jornadas Inter e Pluri-disciplinares, vol. 1, Lisboa, Universidade Aberta, 1993, pp. 195-217.

(7) Vide, sobre o tema, Yves Renouard, Les Hommes d'affaires italiens du Moyen Age, Paris, Armand Colin, 1968, pp.98-106, 316-321, bem como o conjunto de estudos reunidos em El Mediterráneo medieval y renacentista, espacio de mercados y de culturas (Coord. Jaume Aurell), Pamplona, EUNSA, 2002.

(8) Para usar um conceito proposto por Hervé Martin, Mentalités Médiévales. $X I^{e}-X V^{e}$ siècle, Paris, PUF, 1996, p. 405 ss. 
judaicas e mouriscas, especialmente nas cidades do Sul mediterrânico, mas, sobremodo, num patamar socialmente mais fragmentado, dos pobres e marginais, para cujo controle a cidade soube desenvolver mecanismos disciplinadores e contemporizadores.

2. No seio da Coimbra medieval, aquela que agora nos ocupa neste exercício hermenêutico em torno do conhecimento do passado, encontramos topografias distintas às quais corresponderam vivências sociais e culturais diferenciadas ${ }^{(9)}$. Alcáçova, Almedina e suburbia distinguiam-se não somente pela topografia do amuralhamento, como, sobretudo, pela ocupação social diferenciada desses espaços. Na relação dialéctica da vida actual com a tessitura antiga da cidade, encontramos ainda a eloquência impressiva de um mosaico histórico pleno de traços identitários em que parece evidenciar-se a memória de tempos medievais fundadores relevantes.

A Coimbra medieva era, naturalmente, uma cidade rica em representações culturais icónicas e simbólicas. Cidade condal, real e ducal; cidade de cavaleiros e de guerreiros; cidade episcopal e monástica; cidade de aristocracias e de elites; de burgueses e de lavradores; de juristas e de médicos; de trovadores e de jograis ${ }^{(10)}$; de mercadores e de mesteirais; de judeus e de mouros ${ }^{(11)}$; de ricos e de pobres ${ }^{(12)}$. Cidade, ainda, de escolas

(9) Para uma caracterização global da Coimbra medieval, nos mais diversos aspectos históricos, vejam-se os estudos de Maria Helena da Cruz Coelho, "A propósito do Foral de Coimbra de 1179", in Homens, Espaços e Poderes. Séculos XI-XVI. I - Notas do Viver Social, Lisboa, Livros Horizonte, 1990, pp. 105-120; "Coimbra Trecentista. A Cidade e o Estudo", Biblos, Coimbra, vol. LXVIII, 1992, pp. 335-356; "O Infante D. Pedro, Duque de Coimbra”, Biblos, Coimbra, vol. LXIX, Coimbra, 1993, pp. 71-100; Ócio e Negócio em Tempos Medievais, Coimbra, Inatel, 1998; "Coimbra em tempos medievais. (Séculos XIV-XV)", in A História Tal Qual Se Faz, Lisboa, Edições Colibri/Faculdade de Letras da Universidade de Coimbra, 2003, pp. 65-78.

(10) S. Gomes, "Breves observações sobre jograis e cultura urbana na Coimbra medieval", Revista de História das Ideias, vol. 19, 1997-1998, pp. 459-470; A. Resende de Oliveira, Aventures I desventures del joglar gallegoportuguès, Barcelona, Columna, 2001, pp. 11-58.

(11) S. Gomes, A Comunidade Judaica de Coimbra Medieval, Coimbra, Inatel, 2003.

(12) Maria Helena da Cruz Coelho, "A acção dos particulares para com a pobreza nos séculos XI e XIII", Homens, Espaços e Poderes. Séculos XI-XVI. I ..., pp. 78-104. 
(catedralícia, colegiais e conventuais) e do studium generale, estabelecimentos que lhe concederam uma identidade universitária específica ${ }^{(13)}$; cidade, finalmente, sede do concilium municipal e centro de uma complexa rede de hierarquias e sujeições administrativas públicas e locais estendidas ao seu extenso alfoz ${ }^{(14)}$.

Exemplificam tais representações culturais, reais e imaginárias, grandes e pequenos legados da arqueologia urbana do passado, como o selo concelhio de Coimbra, tal como o entrevemos à volta de $1200 \mathrm{ou}$, muito renovado, em meados de Trezentos, em que se projecta a unidade política e social de uma urbanitas conimbrigensis traduzida numa imagem compósita, real e mental, que é interpretação histórica do passado local e, simultaneamente, memoria spiritualis dos seus habitantes.

Demonstram-nas, também, os brasões tardo-medievos da cidade - expressão do entendimento que os conimbricenses de então tinham do seu poder comunitário e gramática elucidativa do avanço da linguagem heráldica em tecidos urbanos - dispersos um pouco por todo o território citadino e peri-urbano e, ainda agora, rememorados em cores violáceas e em logotipos sobreviventes ${ }^{(15)}$.

(13) A Universidade tornou-se uma marca estrutural na construção social da identidade coimbrã, tanto quanto reflecte na sua história, medieva como moderna e contemporânea, as identidades do lugar. Vide Serge Lusignan, "Vérité garde le Roy". La construction d'une identité universitaire en France. (XIII'-XV' siècle), Paris, Publications de la Sorbonne, 1999.

(14) Vide António Gomes da Rocha Madahil, Um conceito medieval de terras do Mondego. Notas de História e de Diplomática, separata da revista Terras do Mondego, Coimbra, Coimbra Editora, 1949; António de Oliveira, A vida económica e social de Coimbra de 1537 a 1640, Primeira Parte, 2 vols., Coimbra, 1971.

(15) Sobre a tradição heráldico-sigilar conimbricense, veja-se: Afonso de Dornelas, "Os selos da cidade de Coimbra. Elementos de estudo", O Instituto, Coimbra, vol. 88, 1935, pp. 5-16; Luís Gonzaga de Lancastre e Távora, O selo medieval de Coimbra e o seu simbolismo esotérico, separata de Armas e Troféus, Lisboa, 1979; V. Correia, “O Brasão da cidade apôsto em casas foreiras”, Arte e Arqueologia, Ano I, n³, 1930, pp. 157-166. No Portugal do século XIV, o gosto pelas temáticas heráldicas foi uma constante. Em 4 de Fevereiro de 1441, por exemplo, o Regente D. Pedro, em nome de seu sobrinho, D. Afonso V, renovou anterior carta de privilégios reais concedidos, em 31 de Dezembro de 1433 ou 1434 a Pêro Afonso Galego, pintor e "mestre dos escudos", morador na cidade do Porto, o qual interpretamos como sendo muito provavelmente "oficial de armas". (Instituto dos Arquivos Nacionais - Torre do Tombo [doravante citado por TT] - Chancelaria 
Evocam-nas, finalmente, a memória do velho pelourinho ou os austeros relevos de capitéis e de pórticos da catedral e de outras igrejas colegiais românico-góticas, as antigas lápides epigráficas outrora expostas em murais de palácios, em escolas, em portas, em torres e pontes, em claustros e lugares fúnebres; tanto quanto essa pujante arquitectura mendicante, a qual pontilhava, enquanto sistema artístico e religioso preenchido por novas ideias estéticas e por novas linguagens pastorais, epicentros de bairros e subúrbios góticos, entre outros monumenta cívicos, militares e religiosos carregados de evidências cenográficas que elucidavam espaços, sociabilidades e identidades culturais endógenas à cidade e que são hoje memória reflexiva de antanho ${ }^{(16)}$.

de D. Afonso V, Livro 2, fl. 85). Sobre os "reis de armas" portugueses veja-se António Machado de Faria, "Introdução", in Livro do Armeiro-Mor. Organizado e iluminado por João du Cros, Lisboa, Academia Portuguesa da História, 1956, pp. XIII-XLI [reeditado pela mesma entidade e Edições Inapa, Lịsboa, 2000]; João Paulo de Abreu Lima, "Oficiais de Armas em Portugal nos Séculos XIV e XV", in Actas do $17^{\circ}$ Congresso Internacional das Ciências Genealógica e Heráldica, vol. II, Heráldica, Lisboa, Instituto Português de Heráldica, 1986, pp. 318-344; Idem, Armas de Portugal. Origem. Evolução. Significado, Lisboa, Edições Inapa, 1998, pp. 143-158. Cf. as perspectivas, sobre este assunto, devidas a M. Pastoureau, Les Sceaux, Turnhout, Brepols, 1981 (Typologie des Sources du Moyen Âge Occidental Fasc. 36); Idem, Figures et Couleurs. Étude sur la symbolique et la sensibilité médiévales, Paris, Le Léopard d'Or, 1986; Aires A. Nascimento, "A heráldica: uma iconografia gramaticalizada. O Livro de Arautos: um instrumento de intervenção diplomática", in A Iluminura em Portugal. Identidade e Influências. Catálogo da Exposição, Lisboa, Biblioteca Nacional, 1999, pp. 333-343.

(16) É muito abundante a bibliografia sobre a cidade antiga como espaço de recepção e de criação artísticas. Seja-nos permitido referir aqui, como bibliografia exemplar, Jacques le Goff, "L'apogée de la France urbaine médiévale, 1150-1330", in Histoire de la France Urbaine, t. II. La Ville médiévale, Paris, Seuil, 1980, pp. 183-405; bem como o conjunto de estudos coordenados por Diana Norman, Siena, Florence and Padua. Art, Society and Religion. 1280-1400, 2 vols., Londres, Yale University Press, 1995. Para Coimbra, veja-se António Nogueira Gonçalves, Inventário Artístico de Portugal, vol. II. Cidade de Coimbra, Lisboa, Academia Nacional de Belas Artes, 1947; Leontina Ventura, "A muralha coimbrã na documentação medieval", separata das Actas das I Jornadas do Grupo de Arqueologia e Arte do Centro, Coimbra, GAAC, 1979; Pedro Dias, A Arquitectura de Coimbra na transição do Gótico para a Renascença. 1490-1540, Coimbra, Epartur, 1982; Maria Helena da Cruz Coelho, Ócio e Negócio em tempos medievais, Coimbra, Inatel, 1998; Luísa Trindade, A Casa Corrente em Coimbra. Dos Finais da Idade Média aos Inícios 
A riqueza material da cidade, gerada pela fecundidade dos agros do seu extenso termo ${ }^{(17)}$ e pela industriosa iniciativa dos seus mesteirais e mercadores ${ }^{(18)}$, atraiu novas gentes e soube sustentar a aparição de elites letradas que reflectiam as necessidades culturais eruditas da própria Coimbra dessas épocas ${ }^{(19)}$. Elites da escrita, servindo escrivaninhas notariais ou de tabeliães, senão mais insignes chancelarias reais, senhoriais e eclesiásticas, como, sobremodo, eruditos copistas, calígrafos e iluminadores, quase sempre experimentados polígrafos, de codices illustres ou de documentos avulsos e epistolares, ao serviço dos scriptoria e das bibliotecas locais ${ }^{(20)}$.

da Época Moderna, Coimbra, Câmara Municipal de Coimbra, 2002; Walter Rossa, DiverCidade. Urbanografia do espaço de Coimbra até ao estabelecimento definitivo da Universidade, Coimbra, Faculdade de Ciência e Tecnologia, 2001; S. Gomes, "D. Gomes Eanes e a Capela de Santo André e dos Cinco Mártires de Marrocos do Mosteiro de Santa Cruz de Coimbra", Arquivo Coimbrão. Boletim da Biblioteca Municipal, Coimbra, vol. XXXV, 2002, pp. 439-540: 439-445.

(17) Maria Helena da Cruz Coelho, O Baixo Mondego nos finais da Idade Média. (Estudo de história rural), Coimbra, Faculdade de Letras da Universidade de Coimbra, 1983.

(18) Maria Helena da Cruz Coelho, "O Povo - a identidade e a diferença no trabalho", in Portugal em Definição de Fronteiras. Do Condado Portucalense à Crise do Século XIV (Coordenação de Maria Helena da Cruz Coelho e Armando L. de Carvalho Homem), vol. III de Nova História da Portugal (Dir. Joel Serrão e A. H. de Oliveira Marques), Lisboa, Editorial Presença, 1996, pp. 278-282; S. Gomes, "A produção artesanal", ibidem, pp. 476-486.

(19) Cf. Maria Helena da Cruz Coelho, "O Estado e as Sociedades Urbanas", A Génese do Estado Moderno no Portugal Tardo-Medievo. (Séculos XII-XV). Ciclo de conferências, (Coordenação de Maria Helena da Cruz Coelho e Armando Luís de Carvalho Homem), Lisboa, Universidade Autónoma de Lisboa, 1999, pp. 269-292.

(20) Vide Maria Helena da Cruz Coelho, "Um testamento redigido em Coimbra no tempo da Peste Negra", in Homens, Espaços e Poderes. Séculos XI-XVI. I - Notas do Viver Social, Lisboa, Livros Horizonte, 1990, pp. 60-77; Idem, "Os tabeliães em Portugal. Perfil profissional e sócio-económico. (Séculos XIV-XV)", Historia, Instituciones, Documentos, Sevilha, vol. 23, 1996, pp. 173-211; Maria José Azevedo Santos, Alguns aspectos do tabelionado em Coimbra (séculos XIV-XV), separata de Arquivo Coimbrão, vol. XXXIII-XXXIV, 1990-92; Bernardo Sá Nogueira, Lourenço Eanes, tabelião de Lisboa (1301-1332): reconstituição e análise do seu cartório, Lisboa, Faculdade de Letras da Universidade de Lisboa, 1988 (policopiado); Idem, Tabelionado e instrumento público em Portugal. Génese e implantação (1212-1279), 3 vols., Lisboa, Faculdade de Letras da Universidade de Lisboa, 1996 (policopiado); 
O livro era, desde sempre e particularmente em contexto judaico-cristão, um instrumento de memória. Da memória das palavras herdadas da revelação divina, das frases de apurada retórica, das ideias dos filósofos e dos patriarcas do saber, dos rituais litúrgicos reiterados nos coros e nos altares. Da memória simbólica em que se gravavam, em elegantes colofones, os nomina dos patrocinadores dessas obras, quase sempre em ordem à sua inscrição entre os rótulos dos justos adormecidos na esperança da ressurreição, cujas identidades urgia lembrar por todos os séculos, tanto quanto a subscrição do escriba ${ }^{(21)}$.

Em códices executados no scriptorium do mosteiro beneditino de S. Mamede de Lorvão, este modelo memorial librário é recorrente. Um modelo marcado pelo princípio da auctoritas bem perceptível no cuidado com que os escribas deste scriptorium beneditino reiteram, nos seus colofones, a informação diplomática acerca dos governantes do cenóbio, do regnum e do bispado, isto é, do mundo político e institucional estritamente hierarquizado em que a instituição se inseria ${ }^{(22)}$.

Antes de 1118, o Abade Eusébio mandaria executar o Liber Testamentorum Laurbanensis, cartulário onde se preservou a memória patrimonial desse cenóbio e, também, a memória social e política da região coimbrã entrevista pelo arquivo zelosamente organizado pelos monges recolhidos nesse claustro. Noutras obras ali copiadas, como no volume da Expositio Sancti Augustini Super Psalmos, executado em 1183, lemos o cólofão:

Idem, "Tabelionado e elites urbanas no Portugal Ducentista (1212-1279)", in Elites e redes clientelares na Idade Média. Problemas Metodológicos. Actas do Colóquio, (Coordenação de Filipe Themudo Barata), Lisboa, Colibri/CIDEHUS - Universidade de Évora, 2001, pp. 211-221; S. Gomes, "O notariado medieval português. Algumas notas de investigação", Hvmanitas, vol. LII, 2000, pp. 241-286; Idem, "Escolares e Universidade na Coimbra Medieval. Breves notas documentais", in Estudos em Homenagem a João Francisco Marques, Porto, Faculdade de Letras do Porto, 2001, pp. 511-531.

(21) A generalidade das epígrafes medievais de Coimbra encontra-se referenciada na obra de Mário Jorge Barroca, Epigrafia Medieval Portuguesa (862-1422), 4 vols., Lisboa, Fundação Calouste Gulbenkian e JNICT, 2000.

(22) Situação comum aos grandes scriptoria monásticos dos séculos XI e XII. Vide Pascale Bourgain, "L'édition des manuscrits", in Histoire de l'Édition Française, t. I, Le livre conquérant. Du Moyen Âge au milieu du XVII siècle, Paris, Promodis, 1992, pp. 49-76, 56-57 e 67-68. 
"Scriptus est liber iste ad laudem et honorem Dei omnipotentis et Sancti Mametis Laubanensis monasterii tempore regis Alfonsi in diebus Iohannis abbatis. Era $M^{a}$. CC.$X X^{a} I^{a}$." Posfácio igual ao aposto no De Avibus, de Hugo de Folieto, manuscrito copiado em Lorvão nesse mesmo ano de 1183.

Trata-se de obras de carácter teológico superior, revelando bem as tendências culturais e espirituais das leituras prosseguidas pelos monges negros de Lorvão no último terço do século XII. Obras feitas para louvor, honra e glória de Deus, mas também para memoria dos governantes e protectores do Regnum e da civitas spiritualis que o próprio cenóbio encarnava.

Em 1185, a hagiografia de Bento de Peterborough, Passio et Miracula Sancti Thome Cantuariensis, redigida cerca de 1170, foi ali copiada. No posfácio, o copista não tergiversou nos louvores aos governadores da cidade terrena, ao Rei Afonso e ao Príncipe Sancho, a Martinho, Bispo de Coimbra, ao Abate nostro Ihoanne e, sobremodo, ao padroeiro espiritual do Mosteiro, S. Mamede e ao Deo uiuo et sanctis suis. Avoca-se, neste cólofão, o mérito do escriba, evidenciado na própria composição rogativa, merecedor da bênção de Deus e da honra, multo tempore, de reis, príncipes, bispos e de todo o clero ${ }^{(23)}$.

No famoso Apocalipse de Lorvão, copiado em 1189, lemos estoutro post scriptum: Iam liber est scriptus. Qui scripsit sit benedictus. Era MCCXXVII. Ego Egeas qui hunc librum scripsi si in alliquibus a recto tramite exiui, deliquenti indulgeat karitas que omnia superat. Amen. ${ }^{(24)}$.

(23) "Explicit liber. Ad honorem Dei et Sancti Mametis laurbanensis monasterii, rege domno Alfonso cum filio sue rege Sancio, imperium obtinent, dominum Martino episcopo Colimbrie Sedi presidente et Abate nostro Ihoanne eidem Laurbanensi monasterio et monachis illic religiose degentibus ministrante, prescribtus est liber iste et perfecte cunsummatus in Era $\mathrm{M}^{\mathrm{a}} \mathrm{CC}^{\mathrm{a}} \mathrm{XX}^{\mathrm{a}}$ III ${ }^{\mathrm{a}}$. Finito libro sit laus et gloria Christo. Qui in Eum adiuuit sit a Deo adiutus. Qui scripturam atulit libri istius in terra ista benedictus sit a Deo uiuo et sanctis suis et uiuat honoratus multo tempore a regibus et principibus suis, ab episcopos et omnibus clericis tam istius terra quam extraneee. Benedicat nos Deus, Deus noster, benedicat nos Deus. Amen."

(24) Os colofones aqui referidos encontram-se comodamente transcritos no artigo de Aires A. Nascimento, "O Mosteiro de Lorvão e o seu scriptorium", in Nos Confins da Idade Média. Arte Portuguesa. Séculos XII-XV (Coord. Luís Adão Fonseca, Mário Jorge Barroca e Lúcia Maria Cardoso Rosas), Porto, IPM, 1992, p. 124. 
A cultura do livro atravessava, na Coimbra desse próspero século XII, momentos de evidente afirmação. Para além de Lorvão, conhecemos bem a acção febril do scriptorium dos Cónegos Regrantes de Santa Cruz de Coimbra, a que se associava, naturalmente, o scriptorium da Catedral e, muito provavelmente, os de outras instituições eclesiásticas da cidade e da sua periferia ${ }^{(25)}$.

O próprio rei $D$. Afonso Henriques ( +1185$)$ não hesitou em associar-se ao engrandecimento da biblioteca da Catedral coimbrã, como se exemplifica com informação documentada alusiva aos dez morabitinos de ouro que doou para a obra do "Testamento Novo"(26). Nesta Catedral, os livros de luxo deveriam ser numerosos. A relação que deles se contém no conhecido Livro das Kalendas, não só os enuncia na sua apreciável quantidade como, invariavelmente, eles estão sempre associados a legados piedosos em favor do thesaurus desta Sé, seja de alfaias litúrgicas preciosas, seja de relicários repletos de taumatúrgicas relíquias dos mais notáveis santos da tradição cristã ${ }^{(27)}$.

(25) Como, a título de exemplo, os Mosteiros de S. Jorge, de Santa Maria de Semide e de Seiça. Algumas outras cidades receberam também livros produzidos nos scriptoria de Coimbra. É o caso da distante Cidade Rodrigo, mas também de Viseu e Lamego. Reconheça-se, contudo, que algumas das Colegiadas de Coimbra estariam igualmente activas quando não na produção, ao menos no consumo de livros, especialmente de liturgia. Isto para além do mercado livreiro próprio do consumo privado de gentes letradas e bibliófilas. Vide Avelino de Jesus da Costa, "Coimbra - Centro de atracção e de irradiação de códices e de documentos, dentro da Península, nos séculos XI e XII", in Actas das II Jornadas Luso-Espanholas de História Medieval, vol. IV, Porto, INIC, 1990, pp. 1309-1334; S. Gomes, In Limine Conscriptionis. Documentos, Chancelaria e Cultura no Mosteiro de Santa Cruz de Coimbra. (Séculos XII a XIV), 2 vols., Coimbra, Faculdade de Letras de Coimbra, 2000, pp. 241-342.

(26) Liber Anniversariorum Ecclesiae Cathedralis Colimbriensis (Livro das Kalendas), (edição crítica de Pierre David e Torquato de Sousa Soares), Coimbra, II vol., 1948, p. 294; Avelino de Jesus da Costa, A Biblioteca e o Tesouro da Sé de Coimbra nos Séculos XI a XVI, Coimbra, Biblioteca Geral da Universidade de Coimbra, 1983, p. 56.

(27) O seu elenco pode consultar-se comodamente na obra de Avelino de Jesus da Costa, A Biblioteca e o Tesouro da Sé de Coimbra nos séculos XI a XVI, Coimbra, Biblioteca Geral da Universidade de Coimbra, 1983, pp. 54-74. 
Esta comunhão espacial de livros, alfaias e relicários, recolhidos ao tesouro da catedral, não deixa de ser sintomática do entendimento que os cónegos conimbricenses tinham acerca dos seus livros, considerando-os peças litúrgicas sacras, como que imbuídas de toda uma memoria spiritualis que estruturava a identidade ritual da Fé que perseguiam ${ }^{(28)}$.

$\mathrm{Na}$ Coimbra desses séculos, contudo, existiam outros espaços consagrados à guarda e à cópia do livro. Não muito diferente do que encontrámos para a Sé catedralícia, seria a situação dos livros da biblioteca dos Cónegos Regrantes de Santa Cruz. Neste cenóbio erguido às portas da cidade, fora de muralhas, a cujo claustro se recolhiam religiosos especializados tanto no saber e na erudição académicos, quanto aptos ao exercício de activas estratégias pastorais no meio das vigararias e paróquias que controlavam canonicamente, a cultura do livro, escolástica ou com intuitos meramente pastorais e religiosos, atingiu o mais elevado grau na cidade do Mondego.

Em Santa Cruz cumpria ao sacrista maior a salvaguarda dos espécimes librários do Mosteiro. Saídos de uma tradição secular, estes Cónegos Regrantes de Santo Agostinho mantinham heranças de antanho, como esta em que os livros da domus Dei se justificavam fundamentalmente porque indispensáveis à oração, ao serviço e ao culto divinos. No thesaurus da sacristia, ou entre esta e a ecclesia, em espaço adequado, repousavam codices illustres, essencialmente vocacionados para as liturgias extremamente solenes em que esta elite de sacerdotes se orgulhava de timbrar. Avançando no século XIII, o ofício de bibliotecário aparece, por vezes, detido pelo cancellarius crúzio, pelo chanceler da comunidade, sintoma de que o livro monástico, neste instituto, merecia as atenções de poderes diversos e permanecia um objecto ao serviço das mais distintas dinâmicas culturais que as diferentes épocas históricas iam conhecendo adentro deste claustro ${ }^{(29)}$.

(28) Éric Palazzo, “Le livre dans les trésors du Moyen Âge. Contribution à

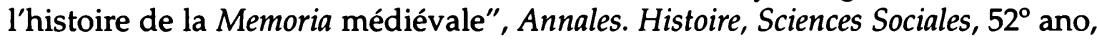
1, 1997, pp. 93-118.

(29) Para uma abordagem mais profunda do caso de Santa Cruz, seja-me permitido remeter para as páginas sobre a biblioteca e o scriptorium crúzios medievos que escrevi em In Limine Conscriptionis. Documentos, Chancelaria e Cultura no Mosteiro de Santa Cruz de Coimbra. (Séculos XII a XIV), Coimbra, 2 vols., Faculdade de Letras de Coimbra, 2000. 
Mas será com os Mendicantes, Franciscanos e Dominicanos, primeiro, mais tarde, ainda, os Hieronomitas e os Eremitas Agostinhos, com mosteiros erguidos nas proximidades da cidade ${ }^{(30)}$, que as bibliotecas conventuais se abrirão às concepções da vida intelectual próprias dos novos tempos. Claustros mendicantes marcados pela pressão das culturas e das linguagens urbanas, verdadeiros epicentros da renovação do saber, em cujos espaços emergem não somente as oficinas predominantemente laicas dos copistas, mais tarde rendidas aos prelos tipográficos, como, sobremodo, se evidencia uma renovada massa de leitores e consumidores de livros de estudo ou de literatura latina e vulgar, de antigos auctores da cultura greco-latina ou de afamados tratadistas e enciclopédicos, que não se recusam ao contacto com o livro em materiais menos tradicionais, como o papel - material de crescente e amplo consumo nos séculos finais da medievalidade - porque matéria de escrita mais económica e, não menos importante, mais funcional para os scriptores e para os lectores, mais-valias que garantiam a plena eficácia dos objectivos de transmissão de conteúdos e de informação erudita ${ }^{(31)}$.

No século XIV, as bibliotecas "urbanizam-se" mais intensamente, acompanhando a progressiva democratização do acesso ao livro, doravante, porque disponível em maiores quantidades e alvo de uma intensa circulação pelas rotas europeias de circulação de homens e de bens materiais, posto ao serviço de universitários e de bibliófilos, de leigos ou clérigos de catedrais e colegiadas, como se apontará entre magnates (reis, rainhas, príncipes, duques, condes e alto-clero) - posto que entre estes predominem os livros de luxo ricamente iluminados e encader-

(30) Lembremos os Mosteiros de S. Marcos de Coimbra (Tentúgal, c. Montemor-o-Velho) e de Nossa Senhora dos Anjos (c. Montemor-o-Velho), o primeiro de frades jerónimos, o segundo de frades eremitas agostinhos. Sem descurar a fundação do convento franciscano de Santa Cristina da Póvoa ou de Tentúgal (c. Montemor-o-Velho), protegido pelos Duques de Coimbra, o regente D. Pedro e sua mulher, D. Isabel de Urgel. Sublinhemos que se trata, ainda, de fundações quatrocentistas.

${ }^{(31)}$ Vide Guy Lobrichon, "La bible d'un maître dominicain de Paris", in Mise en page et mise en texte du livre manuscrit (Dir. Henri-Jean Martin e Jean Vezin), Paris, Promodis, 1990, pp. 181-184; Emmanuel Poulle, "Astronomie et géométrie", ibidem, pp. 193-200; Jacqueline Rambaud, "Les Décrétales", ibidem, pp. 205-210; Robert Marichal, "Les manuscrits universitaires", ibidem, pp. 211-218. 
nados ${ }^{(32)}$ - ou gentes de saber de mais modesta condição social (legistas e notários, médicos, mestres de ensino, mercadores alfabetizados, entre outros profissionais liberais) ${ }^{(33)}$.

Nesta rotação por igrejas seculares e monásticas, pelo studium generale e pelas scholae, encontramos sempre presente o livro e a sua linguagem e escrita latinas ou, paulatinamente, vulgares ${ }^{(34)}$. O livro da oração e o livro da Liturgia, o livro da memória da Teologia patrística cristã, o livro dos jurisconsultos e dos legistas, mas, sobremodo, o livro das bibliotecas urbanas, conventuais, palacianas, municipais ou de particulares dos mais diferentes níveis sociais ${ }^{(35)}$.

3. Os estudos sobre a história do livro manuscrito, dos seus produtores e leitores, em Portugal, nos tempos medievais, têm vindo a conhecer um franco desenvolvimento nos últimos lustros. Os resultados até ora evidenciados, contudo, incidem especialmente sobre as livrarias eclesiásticas quer e sobremodo as monásticas, quer, ainda, as catedralícias e demais colecções privadas de clérigos seculares. De algum modo, este conspecto

(32) Vide Patricia Stirneman, "Les bibliothèques princières et privées aux XII et XIII" siècles", in Histoire des bibliothèques françaises. Les bibliothèques médiévales. Du VI siècle à 1530 (Dir. André Vernet), Paris, Promodis, 1989, pp. 173-192; Françoise Robin, "Le luxe des collections aux XIVe et $\mathrm{XV}^{\mathbf{e}}$ siècles", ibidem, pp. 193-214; Geneviève Hasenohr, "L'essor des bibliothèques privées aux XIVe et XV' siècles", ibidem, pp. 215-264; A. Petrucci, "I libri della porpora", in I Luoghi della Memoria Scritta. Manoscritti, incunaboli, libri a stampa di Biblioteche Statali Italiane (Dir. Guglielmo Cavallo), Roma, Istituto Poligrafico e Zecca dello Stato, 1994, pp. 303-310.

(33) Pierre Cockshaw, "La circulation du manuscrit dans l'Europe médiévale", in Le Livre Voyageur. Constitution et dissémination des collections livresques dans l'Europe moderne (1450-1830), Paris, Klincksieck, 2000, pp. 23-35; Hans Lulfing, "Libro e classi sociali nei secoli XIV e XV", in Libri e lettori nel Medioevo. Guida storica e critica (Coordenação de Guglielmo Cavallo), Roma, Laterza, 1993, pp. 167-230.

${ }^{(34)}$ Arthur L-F. Askins, Aida Fernanda Dias, Harvey L. Sharrer, Fragmentos de Textos Medievais Portugueses da Torre do Tombo, Lisboa, Instituto dos Arquivos Nacionais/Torre do Tombo, 2002, pp. 5-19.

(35) Vide Christopher de Hamel, Une Historie des Manuscrits Enluminés, Hong Kong, Phaidon Press, 1995, p. 108 ss.; Jesús Alturo i Perucho, El llibre manuscrit a Catalunya. Orígenes $i$ esplendor, Barcelona, Generalitat de Catalunya, 2001, pp. 131-208, 180-207. 
heurístico resulta do próprio legado histórico dos tempos medievos, nos quais, na verdade, o Clero, pela sua própria vocação do Religioso que se concatenava numa relação especializada com o campo do saber erudito, assumia um protagonismo quase natural ${ }^{(36)}$.

Neste panorama, aliás, as bibliotecas monásticas, pela sua própria identidade e visibilidade, no passado como nos tempos actuais, ocupam um lugar muito destacado. Tal facto resulta da preservação de um razoável número dos seus espécimes librários - muito em especial no que respeita às bibliotecas dos Mosteiros de Lorvão, de Santa Cruz de Coimbra, de Alcobaça, de Arouca ou de Jesus de Aveiro ${ }^{(37)}$ - ou de registos e inventários dos finais da Idade Média ${ }^{(38)}$ e, sobretudo, dos séculos modernos e contemporâneos que apresentam repertórios catalográficos dessas colecções. As bibliotecas medievais das catedrais portuguesas, contudo, raramente se podem percepcionar pela sobrevivência de exemplares

(36) Vide Isaías da Rosa Pereira, "Manuscritos de Direito Canónico existentes em Portugal", Arquivo Histórico da Madeira, t. XI, 1959, pp. 196-242; "Livros de Direito na Idade Média", Lusitania Sacra, t. VII, 19064/66, pp. 7-60; t. VIII, 1970, pp. 81-96; "Dos livros e dos seus nomes. Bibliotecas litúrgicas medievais", Arquivo de Bibliografia Portuguesa, ano XVI, n ${ }^{\circ}$ 63-70, 1971-1973, Coimbra, Atlântida, 1974, pp. 97-131; "Escolas e livros na Idade Média em Portugal", in Congresso História da Universidade. Universidade(s). História. Memória. Perspectivas. Actas, vol. 1, Coimbra, Comissão organizadora da Congresso, 1991, pp. 55-69; “No XVI centenário do baptismo de Santo Agostinho: as obras de Santo Agostinho nas bibliotecas medievais portuguesas", Anais da Academia Portuguesa da História, Lisboa, $2^{a}$ série, vol. 34, 1994, pp. 100-115.

(37) Vide Inventário dos Códices Iluminados até 1500, vol. I. Distrito de Lisboa; vol. 2. Distritos de Aveiro, Beja, Braga, Bragança, Coimbra, Évora, Leiria, Portalegre, Porto, Setúbal, Viana do Castelo e Viseu. Apêndice - Distrito de Lisboa, (Coord. Isabel Vilares Cepeda), Lisboa, Com. Inventário do Património Móvel, 1994 e 2001.

(38) Pensamos nas bibliotecas claustrais franciscanas arroladas em finais do século XV por ordem de um eminente bibliófilo e confessor régio, Fr. João da Póvoa. Vide Artur de Magalhães Basto, Memórias soltas e inventários do Oratório de S. Clemente das Penhas e do Mosteiro de N. Senhora da Conceição de Matozinhos dos séculos XIV e XV, separata de Boletim da Câmara Municipal do Porto, nº 3-1, 1940; José Adriano Freitas de Carvalho, Nobres leteras... fermosos volumes... Inventários de bibliotecas dos Franciscanos Observantes em Portugal no século XV. Os traços de união das reformas peninsulares, Porto, Centro Inter-Universitário de História da Espiritualidade e do Instituto de Cultura Portuguesa - Faculdade de Letras da Universidade do Porto, 1995. 
codicológicos primitivos, mas tão somente pelas referências inscritas em inventários medievos ou modernos ou pela aparição de fragmentos de códices em núcleos arquivísticos ${ }^{(39)}$.

Para além das bibliotecas medievais das catedrais de Braga e de Coimbra, alvo da erudita investigação do Professor Avelino de Jesus da Costa ${ }^{(40)}$, foi publicado recentemente o mais antigo inventário português datado de uma biblioteca catedralícia portuguesa, a de Santa Maria de Viseu, executado no ano de $1188^{(41)}$, dando-se a conhecer, ainda, actividades de empréstimo de obras da biblioteca catedralícia coimbrã em finais de Quatrocentos ${ }^{(42)}$.

Outras catedrais do nosso território, naturalmente, tiveram as suas bibliotecas medievas, mas a sua elucidação heurística é, ainda, muito embrionária. Esta situação, aliás, afecta outras instituições portuguesas desse tempo, nomeadamente a Universidade, para a qual pouco ou nada possuímos de revelador neste campo - o que nos permite pensar que a biblioteca da Universidade portuguesa medieva deveria ser pouco farta, necessitando os escolares universitários nacionais de suprir as suas próprias necessidades de estudo através da recorrência a reportationes ou a outro sistema de acesso às obras indispensáveis às respectivas aprendizagens ${ }^{(43)}$ - como também alguns Studia das Ordens Mendicantes

(39) Vide António de Vasconcelos, "Fragmento precioso dum códice visigótico", Biblos, n 6, 1929; Avelino de Jesus da Costa, "Fragmentos preciosos de códices medievais", in Estudos de Cronologia, Diplomática, Paleografia e Histórico-Linguísticos, Porto, Sociedade Portuguesa de Estudos Medievais, 1992, pp. 53-108.

${ }^{(40)}$ Avelino de Jesus da Costa, A Biblioteca e o Tesouro da Sé de Braga nos séculos XV a XVIII, separata de Theologica, Braga, 1985; Idem, A Biblioteca e o Tesouro da Sé de Coimbra nos séculos XI a XVI, Coimbra, Biblioteca Geral da Universidade de Coimbra, 1983.

(41) S. Gomes, "Livros e alfaias litúrgicas do tesouro da Sé de Viseu em 1188", Hvmanitas, vol. LIV, 2002, pp. 269-281.

(42) S. Gomes, "Escolares e Universidade na Coimbra Medieval. Breves notas documentais", cit., pp. 530-531. Esta actividade de empréstimo de livros era praticada pela Sé de Coimbra já em pleno século XIII. Veja-se Avelino de Jesus da Costa, A Biblioteca e o Tesouro da Sé de Coimbra..., pp. 70-71.

${ }^{(43)}$ Vide Isaías da Rosa Pereira, "A livraria da Universidade no início do século XVI", Arquivo de Bibliografia Portuguesa, Coimbra, $\mathrm{n}^{\text {os }} 37$ e 38, 1967. 
em Portugal, nos quais se ensinava Teologia, ou, ainda, de alguns colégios para-universitários ${ }^{(44)}$.

Existiram, também, no Portugal medievo, bibliotecas de carácter relativamente público. Pensamos, por exemplo, na biblioteca do Colégio fundado em Lisboa, em 1447, por D. Diogo Afonso de Manganha, para dez escolares, os quais dispunham de uma colecção de livros de estudo deixados pelo instituidor ${ }^{(45)}$.

Havia, por outro lado, no Portugal de Quatrocentos, algumas bibliotecas municipais. OConcelho de Lisboa, por exemplo, emprestava regularmente livros. Conhece-se uma escritura de 28 de Janeiro de 1466, segundo a qual João Fernandes, escolar em Leis, requisitando livros na Câmara olisiponense, apresentava por fiador a seu pai, Fernão de Sintra, pessoa aparentada ao Dr. Pêro Nunes, obrigando-se a restituir à Câmara, bons, limpos e encadernados, como os recebia, "cinquo livros que som huum corpo de Lex, convem a saber: huum Volume, e huum Codigo, e huum Dejesto novo, e outro Dejesto velho e huum Esforçado", livros que haviam sido doados ao Município "para per elles aprenderem escollares e filhos de çidadaãos e parentes seus, que aprender quisessem de Direito"(46).

As bibliotecas privadas de clérigos portugueses dos tempos medievais constituíam, contudo, um elevado número além de que possuíam, frequentemente, livros em quantidades muito apreciáveis. Já no campo laical, tal situação se revela bem mais modesta. Raramente os leigos doaram livros a institutos eclesiásticos, monásticos ou seculares, como raramente

${ }^{(44)}$ Cf. A. Moreira de Sá, Primórdios da Cultura Portuguesa, vol. I, n 1 e $\mathrm{n}^{\circ} 2$ de Arquivos de História da Cultura Portuguesa, Lisboa, 1966 e 1968; Idem, O Porto e a Cultura Nacional nos Séculos XII e XIII, ibidem, vol. II, n² 2, Lisboa, 1968; Francisco da Gama Caeiro, As Escolas Capitulares no primeiro século da Nacionalidade Portuguesa, vol. I, $\mathrm{n}^{\circ} 2$ de Arquivos de História da Cultura Portuguesa, Lisboa, 1966; Idem, A organização do ensino em Portugal no período anterior à fundação da Universidade, ibidem, vol. II, n 3, Lisboa, 1968; José Antunes, A cultura erudita portuguesa nos séculos XIII e XIV (Juristas e Teólogos), (Dissertação de doutoramento; policopiada), Coimbra, Faculdade de Letras da Universidade de Coimbra, 1995, pp. 471-570.

(45) João Pedro Ribeiro, Dissertações Chronologicas e Criticas sobre a Historia e Jurisprudencia Ecclesiastica e Civil de Portugal, t. II, Lisboa, Academia Real das Ciências de Lisboa, 1857, pp. 252-258.

(46) Freire de Oliveira, Elementos para a História do Município de Lisboa, t. I, p. 328; Fortunato de Almeida, História Eclesiástica..., I, p. 464, nota 2. 
os referenciam na sua testamentaria, excepção feita à família real portuguesa e a alguma alta-nobreza cortesã, em cujos testamentos e inventários de bens o livro, em particular o de temática religiosa e espiritual, aparece com certa regularidade. Panorama, aliás, tão mais significativo quanto avançamos para o Quattrocento português, momento em que a Ínclita Geração nos apresenta róis librários bastante impressivos ${ }^{(47)}$ ou nos aparece, mesmo, como sucedeu com $\mathrm{D}$. Afonso $\mathrm{V}$, a patrocinar a constituição de uma grande biblioteca palatina ${ }^{(48)}$.

4. Em 1301, D. João Peres, mestre-escola da Catedral coimbrã, preocupado com a educação de dois seus clientulos, o filho de João Mourisco e Afonso Barreiro, mandava, na sua disposição testamentária, que se vendesse um Breviário.

Da venda desse livro, deveria resultar uma soma de dinheiro suficiente para prover o pagamento de um pedagogo que ensinasse aqueles jovens. Et si non suffecerint denarii istius libri, escreveu aquele cónego, habeant.X.

(47) Como testemunham os inventários das bibliotecas do rei D. Duarte e do Infante D. Fernando. A rainha D. Isabel, filha do infante D. Pedro, Duque de Coimbra, dotou, em 5 de Fevereiro de 1452, o Mosteiro de S. João de Enxobregas, entre outras coisas, com livros da sua biblioteca pessoal: "E mais lhe dou todollas outras minhas Reliquias. E huum dos meus misãaees. E o meu briviairo novo. E os dous livros dos Auctos dos Apostollos e dos Avangelhos." (Instituto dos Arquivos Nacionais - Torre do Tombo [doravante citado por TT] - Chancelaria de D. Afonso V, Livro 13, fl. 119). Vide Aires Nascimento, "As Livrarias dos Príncipes de Avis", Biblos, vol. 69, 1963, pp. 265-287.

${ }^{(48)}$ Em 7 de Março de 1455, D. Afonso V outorga carta de nomeação de ofício de iluminador a Vasco, criado de Luís de Antas, criado del-rei, tomando-o: "novamente por noso ilominador em loguo de huum moço que tiinhamos hordenado a Gonçalo Eanes nosso capelam outrosi noso ilominador porquanto nos praz que este seja filhado em seu loguo e praz-nos que aja de nos deste primeiro dia de Janeiro que ora foy desta presente Era de IIII $^{c}$ Lb em diante dous mil e quatrocentos rreais brancos de mantimento em cada huum anno a rrazom de duzentos rreais por mes os quaes lhe seram pagos em cada huum anno aos quartees delle na nosa portajem desta cidade de Lixboa (...)." (TT - Chancelaria de D. Afonso V, Livro 13, fl. $179 \mathrm{v}^{\circ}$ ). Cf. Sousa Viterbo, A livraria real especialmente no reinado de D. Manuel, Lisboa, 1901; Idem, "A Cultura Intelectual de D. Affonso V", Archivo Historico Portuguez, vol. II, 1904, pp. 254-268; idem, "Calígrafos e Iluminadores Portugueses", O Instituto, nos 8-11, 1916. 
libras de aliis libros quos ego mando vendere. Et dent istos alicui vel aliquibus qui eos doceat uel doceant. ${ }^{(49)}$.

Um outro cónego, D. Francisco Peres, em 1315, doaria a seu criado "Ffrei Vicente os meus livros das Sentenças e os livros que tenho a penhor dos ffrades meores por triinta libras" ${ }^{\prime \prime 50}$. Os livros constituíam, para esses homens, valores seguros de investimento. Valores de mercado, naturalmente, que a cidade, espaço de comércio por excelência, mais incentivava. Porque significavam, em primeiro lugar, uma garantia material de entesouramento, mas, sobremodo, posto que em segundo lugar, porque eles traduziam, para aqueles que realmente os amavam, uma oportunidade de transmissão de uma memória cultural e pessoal traduzida na oportunidade do aprender e do saber. De um "saber" que se tornava apanágio e marca social de famílias e de linhagens urbanas que importava não perder.

D. João de Lourosa, prior de Penacova e cónego com prebendas nas dioceses de Coimbra, do Porto e de Palencia, em 1322, deixava a Gonçalo, seu sobrinho, o "Gieljo que tem seu irmão e o Sexto livro que tem Stevam Perez." Mandava, ainda, a um tal Pedro que "guarde todos os livros da Gramatica que lhi emprestou o abade de Tresmires e que leãm seus sobrinhos per eles. E mando que lhos nom de ata que lhe de o Gonfedro que tem o qual lhi enprestou Antoninho Stevez." (51).

Anos mais tarde, em 1348, espreitando já Coimbra a Peste Negra, o bacharel da Sé, D. Bartolomeu Peirier, elegeria como herdeiros a Raimundo e a Vasco Peirier, seus criados, deixando-lhes "os livros que eu hey com esta condiçom que os nom possam vender ssenom pera os averem elles e sseus ffilhos e netos e sseus subcessores do linhagem pera aprenderem por eles. E sse ffilhos nem ffilhas nom ouverem e eles e elas morrerem extintos mando que fiquem aos [...] da linhagem da sobredicta mha criada Margarida e aaqueles que mays chegados fforem primeyro e souberem

(49) TT - Sé de Coimbra, $2^{a}$ incorporação, m. ${ }^{\circ} 36, n^{\text {os }} 1542$ e 1543. (De 16 de Novembro de 1301, Coimbra).

(50) TT - Sé de Coimbra, $2^{\mathrm{a}}$ incorporação, $\mathrm{m}^{\circ}{ }^{\circ} 25, \mathrm{n}^{\circ}$ 1038. (De 23 de Fevereiro de 1315, Coimbra).

(51) TT - Sé de Coimbra, $2^{\mathrm{a}}$ incorp., m. $.^{\circ} 2, \mathrm{n}^{\circ}$ 53. (De 18 de Julho de 1322, Coimbra). 
leer e quiserem aprender. [...] E sse hy nom ouver nenhuum da linha mando que vendam os dictos livros e que dem os dinheirros por mha alma."(52).

Os livros testemunham, como se referiu, uma herança familiar preciosa. A sua pose denunciava a capacidade económica da família, mas havia que guardá-los e transmiti-los dentro de uma linhagem de alfabetizados que se manteriam, certamente, como personagens de topo na afirmação pública do prestígio dessa mesma unidade familiar, requerendo-se-lhe a entrega e dedicação ao estudo e ao saber, base privilegiada de um cursus honorum em ambiente urbano e fonte de oportunidades sociais em matéria de ocupação de lugares relevantes na administração eclesiástica ou civilista.

5. No fim do mês de Julho de 1306, os tabeliães públicos de Coimbra, Francisco Fernandes e Salvador Domingues dirigiram-se às casas de morada de Rui Domingues. Este beneficiado da Sé de Coimbra desempenhava o ofício de vigário no temporal do bispo D. Estêvão Eanes Brochardo. Doente e pressentindo que "fosse de doença de que a Deus prouguesse de morrer deste mundo", mandara chamar aqueles notários. Contudo, chegados à "pousada", já o dito Rui Domingues estava morto. Acompanhados, então, de Estêvão Gomes, arcediago de Coimbra, e de João Peres, raçoeiro da dita Sé, executores testamentários do malogrado Bacharel, passou-se à inventariação "das cousas que siiam nas casas do dicto Roy Dominguiz"(53).

O inventário é muito pormenorizado, descrevendo minuciosamente uchas e arcas, grandes e pequenas, mobiliário existente, baixela, roupas de vestir e de cama e outros instrumentos domésticos do finado.

Rui Domingues era um importante oficial da burocracia diocesana coimbrã. Nas suas arcas encontrava-se muito dinheiro das rendas do Bispado de Coimbra. Dinheiro cuidadosamente registado nos livros de

(52) TT -Sé de Coimbra, $2^{\mathrm{a}}$ incorp., $\mathrm{m}^{\circ}{ }^{\circ} 25, \mathrm{n}^{\circ}$ 1042. (De 31 de Outubro de 1342, Coimbra). Este e outros dados anteriormente expostos foram já por nós revelados no estudo "A solidariedade eclesial na promoção de escolares pobres a estudos universitários. O exemplo coimbrão dos séculos XIV e XV", in Actas do Congresso "História da Universidade"..., cit., vol. 4, 1991, pp. 195-234, 206-207.

(53) TT - Sé de Coimbra, $2^{\mathrm{a}}$ incorp., $\mathrm{m}^{\circ}{ }^{\circ}$ 93, $\mathrm{n}^{\circ}$ 4425. (De 20... de Julho de 1306, Coimbra). Vide Apêndice documental, $\mathrm{n}^{\circ} 1$. 
receitas e de despesas diocesanos por cuja contabilidade respondia o Bacharel.

Numa arca pequena com cintas de ferro, "jazia huum livro de coyro das rendas do Bispado de Coymbra", relativo ao ano económico de 1305-1306, de S. João a S. João, "en o qual livro avya nove folhas e meya scriptas per espaços assi como en livro de recadaçom." Rui Domingues deixara ainda nessa ucha um outro livro com as rendas dos anos de 1302-1304, com 38 folhas escritas. Um outro caderno com 13 folhas de papel servira à inscrição das despesas dos lugares da Pedrulha e de S. Martinho. Junto deles havia oito libras e quarta e um alvará "posto no saco" alusivo a tais rendas.

Numa outra "arca pequena lavrada e picada", encontraram um livro de receitas e despesas, em papel com 32 folhas escritas "segundo livro de recadaçom". Havia aí, ainda, um esquinino "com cartas seeladas e com stromentos e com dez e nove cadernos e humm Salteyro pequeno", o qual meteram, com a outra arca pequena picada, dentro da ucha grande.

Na câmara onde jazia o defunto, encontravam-se algumas peças da sua baixela de prata. Rui Domingues tinha "dous anees d'ouro, huum com huã çafira quadrada e outra duã lunheta", bem como algumas outras pedras preciosas (topázios e turquesas), para além dos numerosos sacos com dinheiro, maiores e menores, de moeda portuguesa, castelhana "e doutra". Em certos "bolssões novos" guardava dinheiros de cunhagem recente conjuntamente "com cartas e stromentos". Homem de escrita, existia na sua casa "huã mesa e huum scriptorio", descortinando-se outros utensílios indispensáveis ao exercício do escrever como aquela "lanterna de corno" ou, quiçá, "huum castiçal de ferro".

Por entre roupas de vestir e de leito, móveis de pé e arcas, baixela e paramentaria sacerdotal, os inventariantes foram encontrando alguns livros e documentos. Registaram, por exemplo, "cinque livros de fintas os quatro de coyro e huum de papel", "huum saco de linho com cartas e stromentos" e "huum livro de papel pequeno longo". Mas estes, como outros anteriormente citados, são livros de escrita corrente, de contabilidade, com manchas grafemáticas específicas que não escapam à visão profissional dos informados tabeliães presentes ao inventário.

Mais interessantes eram os catorze livros que constituíam esta biblioteca particular. Nela arrolou-se um Saltério, como se referiu, um Breviário, umas Horas de Santa Maria, livros eclesiásticos como um que começava "Exorciso te" e outro que era uma Suma de "sete quinternos 
soltos", iniciando-se pelas palavras "Sante Spiritus gratia". Um "outro livro que se começa Exiit Moyses", poderia corresponder a obra teológica ou patrística. Na sua maioria, contudo, os códices possuídos por Rui Domingues versavam o Direito Civil e Canónico.

Nessa lista encontrava-se um Código( ${ }^{(54)}$, um Degredo ${ }^{(55)}$, uma "Soma de Pedro Sanssom"(56), outra "Soma velha" que se iniciava com as palavras "Iure patronatus"(57), uma "Soma nova" iniciada por "In nomine Domini Jhesu Christi. Ego Egidius"(58), a "Soma Repertoria", o "Sexto livro do papa Bonifacio"(59) e, finalmente, o livro "que chamavam Dos Apostollos com Degretães extraordinarias"(60).

Tratava-se, como se vê, de uma biblioteca relativamente especializada e actualizada para a época em que viveu o seu ilustre possuidor. Por um lado, os livros de oração adequados a um sacerdote secular; por outro, os livros de Direito Canónico, certamente indispensáveis à vida de um jurista que assumira funções de vigário diocesano, cuja actividade forense, como se pode deduzir, era sempre muito intensa.

6. Em pleno período de nojo após a Peste Negra, mais concretamente, em Agosto de 1349, descobrimos uma nova relação de livros, desta feita pertencentes a um António Fernandes. Não sabemos, com rigor absoluto, qual a profissão deste bibliófilo conimbricense. Mas pelo contexto em que é documentado, poderemos propor a hipótese de se tratar de um leigo, talvez jurista, talvez livreiro, em todo o caso, de um burguês.

António Fernandes era irmão de Gil Fernandes, do qual sabemos ter sido advogado. Trata-se, portanto, de alguém integrado numa família de origem burguesa e muito provavelmente coimbrã. Para além do

(54) Provavelmente o Código de Justiniano, talvez com a glosa de Acúrsio.

(55) Decerto o Decreto de Graciano.

(56) Trata-se da Summa Decretalium, de Pedro de Sampson, mestre da Universidade de Bolonha cerca de 1230-1260. (Isaías da Rosa Pereira, "Livros de Direito II", p. 85.

(57) Tratar-se-á do Digesto velho (?).

(58) De difícil identificação. Poderá corresponder ao De regimine principum, de Gil de Roma, escrito em 1285.

(59) Livro Sexto das Decretais.

${ }^{(60)}$ Talvez as Extravagantes de João XXII. 
indicador social que a profissão de advogado do seu irmão nos elucida, a sua rede de relações comunitárias mostra-no-lo em interacção com alguns outros elementos de estrato igualmente urbano-burguês. Estão neste caso os seus testamenteiros, nos quais, necessariamente, depositava uma profunda confiança, a ponto de lhes entregar a responsabilidade da execução das suas últimas vontades.

Um dos seus testamenteiros, efectivamente, foi Estêvão Domingues, mercador de panos, o qual tinha serviçais ou dependentes como Domingos Bartolomeu "homem do dicto". Deste rico mercador de Coimbra, aliás, foi recentemente reconstituída a biografia e percurso, sabendo-se que uma sua filha, Clara Esteves, veio a professar, antes de 1362, nas Clarissas dessa cidade ${ }^{(61)}$. O outro testamenteiro é uma mulher, Inês Martins, da qual sabemos ser senhora de importantes bens a ponto de ter porteiro próprio, a saber, João da Silva. Talvez tenha sido por via desta Dona que este documento, atestando bens que lhe foram confiados, entrou no cartório do Mosteiro de Santa Clara de Coimbra, cenóbio a que, muito provavelmente, terá recolhido.

Do inventário dos bens de António Fernandes constam 25 códices e 18 anéis de ouro, prata e latão com pedras preciosas encastoadas. Trata-se, como se vê, do elenco de um tesouro particular. Livros e jóias associam-se no percurso do burguês António Fernandes, recordando uma relação antiga e sagrada entre livros e objectos de ourivesaria.

A biblioteca de António Fernandes era constituída por livros de Direito Civil e Canónico (10 volumes e três tomos com vários cadernos de textos jurídicos), de Teologia e Oratória (8 volumes) e de assuntos diversos como um formulário de ars dictaminis ("Notaria, fformas de notas"), um livro de receitas curativas ("Meezinhas") e dois outros volumes, um versificado "das Hervas" e outro "que era de ffiguras de Meestre Appellanie". Assuntos que, de alguma forma, podem indiciar estarmos perante uma personalidade aberta às temáticas jurídicas e às práticas notariais, mas também às novas tendências religiosas de Trezentos - neste sector, aliás, com particular relevância para obras próprias de uma espiritualidade moderna, como se deduz do seu empenho intelectual num "Livro dos Eyxenpros de Pregar" ou na obra

(61) Maria Helena da Cruz Coelho, "Homens e Negócios", in Ocio e Negócio em Tempos Medievais, Coimbra, Inatel, 1998, pp. 127-202, 142-145. 
de Raimundo de Penaforte, "ffrade dos Pregadores ssobre peendenças ${ }^{(62)}$ e outras vidas" - e, ainda, a uma interessante propensão para temas de carácter eventualmente farmacológico ou medicinal ${ }^{(63)}$.

7. Data de 1404 a relação dos livros deixados por D. Rui Lourenço, Deão que fora da Sé de Coimbra, aos Cabidos das Sés de Lisboa, de Coimbra e de Silves. Estamos perante uma extensa biblioteca com 56 títulos ou obras, conquanto distribuídos por 51 volumes. Álvaro Martins, seu sobrinho e testamenteiro, recorda o ilustre bibliófilo conimbricense como parente "de Boa Memoria".

Rui Lourenço foi embaixador do rei D. Fernando, em 1380, para tratar do casamento da Infanta D. Beatriz com D. Henrique, filho do Rei de Castela. Em 1382, o Monarca consultá-lo-ia sobre o problema do Cisma da Igreja e do retorno à obediência de Avinhão. Rui Lourenço seria um dos signatários do "auto de eleição" de D. João I nas Cortes de Coimbra de 1385. Conselheiro de D. João I, membro do Desembargo real, foi cónego de Coimbra - onde veio a ser Deão - e de Lisboa, bem como Prior da Colegiada de Santa Maria de Guimarães. Terá falecido por finais de 1404, pois em Outubro desse ano tratava-se da execução do seu testamento ${ }^{(64)}$.

O inventário dos seus livros prendeu-se com a necessidade da divisão desse espólio pelas três instituições beneficiadas. Razão por que, na maioria, os volumina aparecem avaliados em dobras, facto raro no campo da história do livro manuscrito medieval português. Por esse leque de preços, verificamos que os valores de tais códices iam desde uma dobra até às 16 ou 18 dobras. São frequentes os códices avaliados em duas, três e cinco dobras, como, num patamar superior, os volumes de sete, oito ou dez dobras.

(62) Tratar-se-á, aqui, da obra Summa de Poenintentiae, referente a questões de Direito Canónico. Vide Isaías da Rosa Pereira, "Livros de Direito...", II, p. 95.

(63) Botânica e farmacologia entrevêem-se nos títulos "Livro de Meezinhas" e do livro "das Hervas". O caderno das "ffiguras de Meestre Appellanie", de difícil identificação, poderá remeter a tratadística na área da Medicina. Vide Apêndice, $n^{\circ} 2$.

(64) A biografia deste Deão foi já estabelecida por A. L. de Carvalho Homem, O Desembargo Régio (1320-1433), Porto, INIC-Centro de História da Universidade do Porto, 1990, pp. 382-383. 
A identificação dos códices é dada pelo título e, por vezes, pelo respectivo autor. Referências claramente eficazes para os letrados que se interessavam pelo universo do saber jurídico nos alvores do século $\mathrm{XV}$. Ainda assim, nalguns casos, $\mathrm{o}$ inventariante valoriza a antiguidade do manuscrito ou a sua qualidade paleográfica e decorativa. É o caso, a título de exemplo, de "huuã leitura sobre as Degretaaes e Ignota que tem huum $\mathrm{G}$ fremosso no começo e boas tavoas e boons prugaminhos".

Este é um tipo de informação excepcional. Tenhamos em conta que, em boa parte, muitos destes livros, escritos sobre papel, não comportariam grande trabalhado de iluminação, além de que esta, em manuscritos de estudo e trabalho jurídicos, nem sempre se justificava, dado o sentido prático e forense de tais instrumentos de leitura.

Biblioteca essencialmente de jurista e de político, a avaliar pela presença de um "livro de papel em que falla dos tractados da emliçom do papa Urbano sobre a Çixma", sendo poucos os livros fora desse âmbito. Entre estes, assinalemos um volume com textos de Santo Isidoro de Sevilha, um Tratado de Teologia "que se começa Investe poderis" junto do qual estava um "Reportorio do Especullo em boa letera e em boom volume", "huum livro das Eticas" e, como se esperaria numa colecção de livros de um eclesiástico, um Breviário Santoral, um Ordinário, um caderno do ofício de S. Francisco, em "maa letera", e um livro pequeno de "poetaria" intitulado Flores de Gramática. Tudo o mais versava temáticas próprias do Direito e da respectiva tratadística.

8. Cónegos e leigos eram, na Coimbra medieval, públicos que cultivavam um gosto muito particular pelo livro. As bibliotecas privadas variavam em número. Encontramos testemunhos de gente com apenas um ou dois códices, como podemos verificar a existência de bibliófilos com dezena e meia ou duas dezenas e meia a meia centena de livros. Números que, quando se tratava de livrarias de bispos ou do demais alto-clero, se elevavam frequentemente às muitas dezenas ${ }^{(65)}$. Livros a

(65) Daniel Williman, Bibliothèques Ecclésiastiques au Temps de la Papauté d'Avignon. I. Inventaire de bibliothèques et mentions de livres dans les Archives $d u$ Vatican (1287-1420) - Répertoire. II. Inventaires de prélats et de clercs non français - Édition, Paris, CNRS, 1980, pp. 36, 41, 59, 116-117, 159170, 179, 219-221, 232, 240-242, 266-268; Isaías da Rosa Pereira, "Livros de Direito...", passim. 
que corresponde sempre um elevado valor pecuniário. Talvez essa seja uma das razões por que tais códices continuam a surgir, nos inventários ou nos testamentos, quase sempre associados ao tesouro doméstico do respectivo bibliófilo.

Enquanto cidade de elites bibliófilas, a Coimbra medieval conhecia, certamente, numerosas outras bibliotecas. Conventos, colegiadas, paróquias citadinas ou peri-urbanas eram instituições nas quais o livro, pelo menos o livro litúrgico, se encontrava presente. Outros institutos urbanos como confrarias, albergarias ou hospitais guardariam também nos seus arquivos e armários livros de contas correntes como, porventura, alguns códices de finalidade religiosa ${ }^{(66)}$.

As bibliotecas privadas de altos eclesiásticos, de cónegos e de beneficiados, como as de leigos, fossem elas de homens ou de mulheres, de reis ou de nobres, de juristas ou de notários, de médicos ou de cirurgiões, de mercadores ou de mesteirais, de judeus ou de outros elementos moradores na cidade, multiplicaram-se até aos alvores de $1500^{(67)}$.

Chegado a este ponto, naturalmente, o livro manuscrito concorria, em desvantagem, com a proliferação do livro produzido pela recém-nascida imprensa tipográfica ${ }^{(68)}$. $\mathrm{O}$ aparentemente frágil suporte que era o papel tipográfico, nesse momento, não constituía propriamente um obstáculo mental à leitura desses novos livros. Em Coimbra, por exemplo, como se verificou pelos casos documentais anteriormente

(66) Este tipo de situação verificava-se particularmente nas grandes e médias cidades. Vide Armando Petrucci, "Le biblioteche antiche", in Letteratura italiana. vol. II. Produzione e consumo, Roma, Giulio Einaudi Editore, 1988, pp. 528-553; Jesús Alturo i Perucho, El llibre manuscrit a Catalunya..., pp. 145-169; Josep Antoni Iglesias i Fonseca, "Livres et lecteurs à Barcelone au XVe siècle. L'exemple des artisans", Scriptorium. Révue Internationale des Études Relatives aux Manuscrits, L (1996-2), pp. 380-389.

(67) Jeús Alturo i Perucho, ob. cit., pp. 180-207; Richard H. Rouse e Mary A. Rouse, Manuscripts and their makers. Commercial book producers in Medieval Paris. 1200-1500, vol. 1, Turnhout, Harvey Miller Publishers, 2000, p. 99 ss.; Miguel Torres i Cortona, Les Biblioteques dels Jurisperits, Notaris $i$ Escrivans a Manresa al segle XIV, Barcelona, Universitat Autonoma de Barcelona, 2003 (policopiado).

${ }^{(68)}$ Lotte Hellinga, "La constitution des collection d'imprimés en Europe du Nord au XVe siècle", in Le Livre Voyageur..., pp. 37-51; Eduardo Barbieri, "L'accueil de l'imprimé dans les bibliothèques religieuses italiennes du Quattrocento", ibidem, pp. 53-91. 
referidos, o papel é um material de escrita corrente nas casas de letrados, fossem elas de eclesiásticos ou de leigos. De toda a forma, a mancha óptico-grafemática dos livros manuscritos em pergaminho prolongava-se no incunábulo impresso em papel.

As vantagens do livro impresso eram, de todos os pontos de vista, muito atractivas para bibliófilos e amantes do saber. Mas, num ou noutro suporte, em pergaminho ou em papel, o que importava, realmente, era a continuidade da vocação da cidade como espaço plural de culturas urbanas, dentre as quais, o grupo sócioprofessional dos letrados se revelava uma elite cada vez mais complexa e entreaberta ao recrutamento alargado de novos membros oriundos de estratos sociais muito diversificados.

O mérito do sucesso desse longo processo civilizacional titulado pelo livro, o livro feito memória do espírito, da inteligência e do saber, memória de lugares e de gentes, teve na Coimbra medieval, como em todas as outras cidades, um interlocutor significativo. Da cidade medieval, casa de livros, ascendemos à biblioteca moderna barroca e contemporânea, ela própria uma cidade interior. Como se as cidades e os seus livros se confundissem numa única e mesma composição pictural da memória do Homem, povoada, como a cidade de outrora de Ambrogio Lorenzetti, de monumentos admiráveis, de referências inesquecíveis, de afectos amorosos como aqueles que prendem os homens esclarecidos aos livros de todas as vidas. 


\section{Apêndice Documental}

Doc. 1

1306 JULHO, 20..., Coimbra - Inventário dos bens móveis possuídos por Rui Domingues, raçoeiro da Sé de Coimbra e vigário de fora do Bispo D. Estêvão Anes Brochardo. Entre esses bens encontravam-se, para além do mobiliário e da roupa de cama e de vestir, diversos livros, em pergaminho e em papel, da "recadaçom" ou receitas e despesas do Bispado, sacos com documentos, códices de Direito e outros objectos do "scriptorio" do mencionado eclesiástico.

TT - Sé de Coimbra, $2^{\mathrm{a}}$ incorporação, m. ${ }^{\circ} 93$, doc. 4425

Obs.: Documento delido no canto inferior direito.

Refa: Avelino de Jesus da Costa, "Arquivos eclesiásticos", Dicionário de História da Igreja em Portugal (Dir. Alberto Banha de Andrade), vol. I, Lisboa, Resistência, 1980, pp. 515-553: 522; S. Gomes, In Limine Conscriptionis. Documentos, Chancelaria e Cultura no Mosteiro de Santa Cruz de Coimbra. (Séculos XII a XIV), Coimbra, vol. 1, Faculdade de Letras de Coimbra, 2000, p. 306.

E'no nome de Deus amen. Conhoscam quantos este stromento virem, como Roy Dominguiz raçoeyro da See de Coynbra e vigayro no tenporal do honrrado padre e senhor Dom Stevam pela graça de Deus Bispo da dicta cidade doente fosse de doença de que a Deus prouguesse de morrer deste mundo e que tevesse por bem ante ora da sa morte de querer fazer e ordinhar seu testamento segundo a ssa prostumeira voontade poys doente era de doença que era morte natural. Eu Ffrancisco Fernandiz publico tabelliom da cidade de Coynbra com Salvador Dominguiz tabelliom dessa meesma yndo a mandado do dicto Roy Dominguiz pera fazer seu testamento como el mandasse e por bem tevesse foy assi que nos na sa pousada achamos ja o dicto Roy Dominguiz morto. E logo entom Stevam Gomes arcediagoo de Coynbra e Joham Perez pervendeyro da dicta See que se deziam executores ou testamenteyros do dicto Roy Dominguis teverom por bem e rogarom mi davandicto tabelliom que fosse screver aquelas cousas que siiam nas casas do dicto Roy Dominguiz. E eu a rrogo deles ${ }^{(69)}$ screvi aquelas cousas que eessas casas perdante mim parecerom as quaes se seguem eesta maneyra:

(69) Corrigiu "deles". 
Primeyramente achamos huã ucha frances grande e bõa na qual ucha foy achado huã almucela [v]yada e huum faceyroo lavrado pequeno e dous mantees.

Item huuns mantees grosos.

Item huã peça de lenço e dous lenções e huã fronha d'almadraque.

Item huum saco com dinheyros velhos come meyado saco come pequeno.

Item huum estoque.

As quaes cousas forom logo metudas na dicta ucha.

Item huã mesa nova.

Item dous escanos.

Item huã arca pequena.

Item huum banho de tavoas.

Item huum leyto com tavoas.

Item lareyro e huum castiçal de ferro.

Item huã taça com pee.

Item duas taças sem pees picadas.

Item huum tavoleyro com tavolas e com acedreche e duas bolssas com esses trebelhos.

Item huum almofreyxe velho de pano.

Item huum tabardo com seu caparom de brao.

Item huum pelote de pres craro.

Item huum manto de sarda negra com pena branca.

Item huã capa de coro.

Item huum par de calças velhas cardeas.

Item huum cobertor com pena ja velho.

Item huã arca pequena com cintas de ferro na qual jazia huum livro de coyro das rendas do Bispado de Coymbra da Era de mill trezentos e quareenta e tres, des dia de Sam Oane ata a Era de mill trezentos quareenta e quatro annos ata o outro dia de Sam Oane segundo como eesse livro parecia en o qual livro avya nove folhas e meya scriptas per espaços assi como en livro de recadaçom.

Item outro livro de coyro da renda do Bispado des dia de Sam Oane da Era de mill trezentos e quareenta ata dia de Sam Oane da Era de mill trezentos quareenta e dous annos assi como en el parecia e contiinha en ssi trinta e oyto folhas scriptas assi como parecia eesse livro.

Item huum caderno de papel de despesa do Bispado da Pedrulha e de Sam Martinho assi como en el parecia e era conteudo no qual se contiinha treze folhas. 
Os quaes livros forom metudos na dicta arca com oyto libras e quarta que en ela siiam segundo o alvara posto no saco.

Item huã arca pequena lavrada e picada na qual siiam fintos e huum livro de papel scripto que tiinha en ssi trinta <e duas> folhas scriptas segundo livro de recadaçom e era de recepta e de despesa assi como parecia, o qual livro foy metudo na dicta arca.

Item huum esquinyno com cartas seeladas e bom stromentos e com dez e nove cadernos e huum Salteyro pequeno o qual esquinyno meterom na dicta ucha grande frances e outrossi a arca picada.

Item dous cuytellos de mesa e huum ricel e huum soonbreyro velho e huãs luvas.

Item foy achado en huum saco trinta e quatro libras e oyto soldos e VII dinheiros que filhou o dicto Joham Peres pera a sopoltura do dicto Roy Dominguis.

Item huãs botas velhas e huuns botões.

Item huã ucha grande e bõa que siia na camara hu jazia o dicto Roy Dominguis, na qual ucha foy achado huum vaso e huã tagara de prata.

Item sex colheres de prata com sa baynha.

Item huum covedo de pano de negra assi como pareçia.

Item huum agomyl.

Item huum envestidoyro d'almucela novo assi como parecia.

Item huum soonbreyro e huãs luvas.

Item tres faceyroos lavrados.

Item huum pano novo de cocedra acedrenchado.

Item duas fronhas de Faceyroos lavradas.

Item huãs toalhas novas.

Item dous mantees pequenos novos.

Item huã cinta de seda ja treyta.

Item Brevyayro.

Item quatro lenções.

Item tres mantees novos grandes e huã sobrepeliza.

Item outras toalhas.

Item huum esquinino pequeno com dous anees d'ouro, huum com huã çafira quadrada e outra duã lunheta.

Item tres topaças e huum grão de torquesa desencastoadas.

Item dous par[es] de cordões e huãs tisoyras e huum canyvete de mãgo d'almafi com tisoyras e huã baynha. 
Item huum saco de linho com cartas e stromentos.

Item huum livro de papel pequeno longo.

Item tres sacos com dinheyros e meterom os dous meores no mayor.

Item quareenta e tres torneses.

Item dez e nove pares de dinheyros castelães e doutra moeda.

Item huum manto duã verde com pena branca.

Item dous lençoes cruus.

Item outro par de botas novas.

Item huum açafate mourisco.

Item dous pães e meyo de cera.

Item muça velha.

As quaes cousas forom metudas e tornadas aa dicta ucha.

E de mays foy hy metudo huum livro que chamam Codigo assi como deziam.

Item outro livro que se começa Exiit Moyses.

Item huum Degredo assi como deziam.

Item huã Soma de Pedro Sanssom assi como deziam.

Item outra Soma velha, assi como deziam que se começa Iure patronatus.

Item outra Soma assi como deziam e começa sse In nomine Domini Jhesu Christi. Ego Egidius.

Item cinque livros de fintas os quatro de coyro e huum de papel.

Item huum livro ecresiastico que se começa Exorciso te.

Item huã Soma de sete quinternos soltos que se começa Sante Spiritus gratia et ct.

Tod'esto jaz na dicta arca de susodicta.

E de mays aynda ficou eela huã Soma Repertoria assi como deziam.

Item o Sexto livro do papa Bonifacio assi como deziam.

Item outro livro que chamavam Dos Apostollos com Degretães extraordinarias.

Item fora dessa arca foy achado huum pelote de saria velho e outro de brao e huã saya de pres claro velha.

Item huã cinta de coyro pera camynho.

Item tres napeyras e huãs bescalças de coyro.

Item huã aljaveyra de coyro.

Item huã ucha pequena sem cintas en que seem quatro mantees novos e dous barretes e huã cinta de seda verde sem pariho (?) e huãs Oras de Sancta Maria.

Tod'esto ficou entom na dicta ucha. 
Item en outra ucha ferrada grande frances foy achado huum correyo com dinheyros novos.

Item dous bolssões novos anbos en huum com dinheyros novos e com cartas e stromentos e todo entom ficou na dicta arca.

Item outra arca com huã soma de pregos.

Item tres colchas brancas duas velhas e huã nova.

Item huum coyro vermelho de leyto.

Item huã mesa e huum scriptorio.

Item huum saco en que andava huã fronha velha d'almadraque.

Item huuns mantees novos e grossos.

Item peça de pano de comentos cruu pequena.

Item huã almucela vyada nova.

Item huã fronha de chumaço lavrada.

Item huã pena purada pera cobertor.

Item andava en huum lençol huã colcha ondada.

Item huã lanterna de corno.

Item huã caldeyra pequenyna velha de cobre.

Item huum branco.

Item huã podadoyra.

Item huã mua nova ${ }^{(70)}$ de seu corpo e huã muacha e huã azemela.

Item outra taça de prata pequena que foy de vaso.

Item huã cocedra velha com pena.

Item outra listada com pena.

Item huã de pena com sa fronha.

Item huum almadraque de laa.

Item huum cabeçal longo listado com pena.

Item outro chumaço chão com pena.

Item huã colcha cardea d'algodom.

Item outra colcha cardea com laa.

Item huã colcha velha d'algodom.

Item huã colcha velha e branca.

Item dous lençoes pera leyto.

Item huum almadraque de freyxeal e dous almadraques de laa e tres faceyroos.

Item tres chumaços velhos de tear.

Item huum almofreyxe.

Item huã bacia grande e outra pequena e huum agomyl.

${ }^{(70)}$ Esta palavra foi subpontada. 
Item dous chumaços acedechados, huum com fronha lavrada e outro sem fronha e outros dous lençoes.

Item huuns mantees e huãs toalhas.

Item duas pipas e onze taalhas vazias pera azeyte.

Item huã masseyra grande pera fazer pam com sa cobertoyra.

Item cinque odres.

Item antre escudelas e talhadores viinte e huum e huum molhador.

Item huã caldeyra pera cozinha.

Item dous alqueires e huãs greelhas e huãs tripees.

Item huum tavoleyro de pam e huã masseyra pera pam.

Item dous bacões.

Item no celeyro do pam milho peça del e cevada e trigo pouco.

E eu davandicto tabelliom a rrogo dos dictos Arcediagoo e Jhoam Perez que se deziam testamenteyros do dicto Roy Dominguis a todas estas cousas de susodictas como dicto he presente fui e as dictas cousas que perdante mim parecerom en publica forma tornei e este stromento ende fiz com mha mão propria screvi e em el este meu sig (sinal) nal posi en testemoynho das dictas cou[sas].

Esto foy feyto en Coymbra nas casas que forom do dicto Roy Dominguis vii[nte ...] de Julho da Era de mill e trezentos e quareenta e quatro annos. Que presente forom Jhoam ... de Coymbra, Salvador Dominguis tabelliom dessa meesma e outros testemunhas.

\section{Doc. 2}

1349 AGOSTO, 17 e 27, Coimbra - Registo da entrega feita a Inês Martins, de parte dos bens que haviam sido de António Fernandes, irmão de Gil Fernandes, advogado de Coimbra, por parte dos seus testamenteiros, Afonso Peres, alvazil, $e$ Estêvão Domingues, mercador, ambos de Coimbra. Entre esses bens contavam-se sobretudo códices.

\section{TT - Santa Clara de Coimbra, $\mathrm{m}^{\circ}{ }^{3}$, doc. 43.}

Sabham todos quantos este stromento virem como dez e ssete dias d'Agosto da era de mil e trezentos e oyteenta e ssete anos, na cidade de Coymbra antre as casas de Stevam Dominguez mercador em presença de mim Angelo Perez publico tabeliom de nosso ssenhor El Rei na dicta cidade presentes as testemunhas adeante scriptas, Apariço Martinz porteyro jurado do conçelho da dicta cidade disse da parte d'Affonso Perez Peyxeiro alvazil da dicta cidade come a testamenteyro que era 
d'Antonio Fferrnandez ao dicto Stevam Dominguez mercador que dos beens que tiinha do dicto Antonyo Fferrnandez cujo testamenteyro era que lhes desse delles tantos per que conprisse huum stromento de sentença que lhi o dicto alvazil mandava conprir en trezentas e viinte e duas libras e meia. E logo o dicto Stevam Dominguez veendo o que lhi dizia o dicto porteiro por mandado do dicto alvazil disse que queria conprir sseu mandado. E logo o dicto Stevam Dominguiz deu ao dicto porteyro dos beens que dizia que fforom do dicto Antonio Fferrnandez cujo testamenteyro el era tres livros os quaes dizia que aviam nome huum delles

[1] Digesto Velho

[2] e outro Speculo

[3] e o outro Leytura ssobrelas Degretãaes.

O qual stromento da dicta ssentença era por razom de trezentas libras que o dicto Antonyo Fferrnandez en sseu testamento mandara que dessem a Gil Fferrnandez vogado que ffoy da dicta cidade sseu irmãao. Das quaes livras que assi fforom entregues ao dicto porteiro como dicto he o dicto Stevam Dominguez pediu ende huum stromento. Ffecto ffoy no logo dia mes e era ssobredictos, testemunhas que presentes fforom Christove Anes procurador do dicto conçelho e Andre Anes procurador no dicto concelho e outros. E eu Angelo Perez tabeliom ssobredicto a esto presente ffoy e a rrogo do dicto Stevam Dominguez este stromento screvy e aqui meu ssignal ffiz que tal (sinal) he, en testemunho de verdade.

Pagou o dicto Stevam Dominguez deste stromento e do registo cemto e seys soldos(?).

Sabham quantos este stromento virem como viinte e ssete dias d'Agosto da era de mil e trezentos e oyteenta e ssete annos na cidade de Coynbra nas casas da morada de Eynes Martinz molher que ffoy de Joham Perez prebendeyro e testamenteyra d'Antonio Fferrnandez en presença de mim Angelo Perez publico tabeliom de nosso ssenhor El Rei na dicta cidade de Coymbra e das testemunhas adeante scriptas Stevam Dominguez mercador morador e vizinho da dicta cidade e testamenteyro do dicto Antonio Fferrnandez deu e entregou aa dicta Eynes Martinz estas cousas que sse adeante sseguem, as quaes dizia o dicto Stevam Dominguez que fforom do dicto Antonio Ffeerrnandez cujo testamenteyro era.

[4] Primeyramente huum livro que dizia que chamavam Innocencio.

[5] Item outro livro pequeno que chamava Mandagoto.

[6] Item outro livro pequeno que chamam Texto de Ssexto Livro.

[7] Item outro que chama s[e] de Tranquedo Rethorica.

[8] Item outro livro que chamava Johane de Deo. 
[9] Item outro livro que chaman Leytura ssobrelo Sseixto Livro.

[10] Item outro livro que chamava Texto d Estatuta.

[11] Item outro livro que chamava Livro dos Eyxenpros de Pregar.

[12] Item outro livro que chamava de scriptos meudos que perteeçiam aa Egreja.

[13] Item outro livro que chamam da Ordinhaçom da Conssegraçom da Egreja.

[14] Item outro livro que chamavam do offiçio do Corpore Christi.

[15] Item outro livro que chamava Conpillaçom da Ordem do Juyzo.

[16] Item outro livro que chamava Exposições das Pallavras de Sancta ${ }^{(71)}$ Scriptura.

[17] Item outro livro que chamava da Payxom de Ramos.

[18] Item outro livro que chamava livro conposto por Reymundo ffrade dos Preegadores ssobre peendenças e outras vidas.

[19] Item outro livro que chamava Notaria fformas de notas.

[20] Item outro livro que chamava Livro de Meezinhas.

[21] Item outro livro que chamava que era verssifficado das Hervas.

[22] Item outro livrete ${ }^{(72)}$ que chamava Novas Constituições do papa Clemente.

[23] Item huum caderno de texto de Statuta.

[24] Item çinque cadernos de Cexto de Seisto livro(73).

[25] Item outro caderno que diziã que era de ffiguras de Meestre Appellanie.

Item lhi fforom entregues aa dicta Eynes Martinz por o dicto Stevam Dominguez dezoyto aneees dos quaes anees pareçiã que eram ende os ssete d ouro todos com ssas pedras e os dous pareçiam de prata com duas pedras grandes huã dellas cardea e a outra vermelha yndea. E os outros dous pareçiam d alatom com ssas pedras. $\mathrm{E}$ os outros ssete pareçiam de prata com ssas pedras. E assi ssom per todos os dictos dezoyto anees. d ouro.

Item huã pedra pequena que andava em huum castom que pareçia

Item duas pedras $\mathrm{d}$ anees liadas em huum pano. A huã dellas cardea e a outra vermelha.

\footnotetext{
(71) Riscou a palavra: "Egreia".

(72) Leitura proposta a partir da palavra abreviada "liuret."

(73) Sic.
} 
Os quaes livros e cadernos e anees e pedras lhi fforom entregues todos aa dicta Eynes Martinz como dicto he com huã arca fferrada em que as dictas cousas ssiiam. E logo a dicta Eynes Martinz sse deu de todo por entregue. As quaes cousas todas com a dicta arca dizia o dicto Stevam Dominguez que fforom d Antonio Fferrnandez cujos testamenteyros os dictos Stevam Dominguez e Eynes Martinz deziam que eram. Das quaes cousas o dicto Stevom Dominguez pediu a mim ssobredicto tabeliom huum stromento. Ffecto ffoy no logo dia mes e era ssobredictos.

Testemunhas que presentes esteverom. Ffruytoso Dominguez çapateyro e Domingos Bertolameu homem do dicto Stevam Dominguez e Joham da Ssilvãa porteyro da dicta Eynes Martinz e outros. E eu Angelo Perez tabeliom ssobredicto a este presente ffoy e a rrogo e per outorgamento dos dictos Stevam Dominguez e Eynes Martinz este stromento escrevy e aqui este meu ssignal ffiz que tal (sinal) he. Em testemunho de verdade.

Pagou o dicto Stevam Dominguez deste stromento com o registo e com os caminhos cemto sex ssoldos.

Doc. 3

1404 OUTUBRO 13, Coimbra - Pública-forma da quitação, efectuada em Lisboa a 29 de Agosto de 1404, dos livros deixados por D. Rui Lourenço, antigo deão da Sé de Coimbra, aos Cabidos das Sés de Lisboa, Coimbra e Silves, da qual fora executor Alvaro Martins, sobrinho do legatário.

TT - Sé de Coimbra, $2^{\mathrm{a}}$ incorp., m. $^{\circ} 94$, doc. 4498.

Pub.: Avelino de Jesus da Costa, A Biblioteca e o Tesouro da Sé de Coimbra..., pp. 201-203(74).

Sabham quantos este estormento virem como treze dias d Outubro Era de mil e quatrocentos e quareenta e dous annos na cidade de Coinbra na clastra da see cathedral no logo honde os coonigos e cabidoo da dicta see acustumam de fazer cabidoo, Seendo hi os honrrados senhores Pero Gonçallvez chantre e os coonigos e cabidoo da dicta see juntos em cabido e cabidoo fazendo como he de seu custume perante elles e presente mim Pedr'Afomso publico tabelliam por El Rei na dicta cidade e das testemunhas que adeante som escriptas, pareçeo Alvaro Martinz sobrinho e

(74) A leitura que apresentamos deste documento apresenta diferenças em relação à referenciada, razão que nos leva a reeditar este importante auto. 
testamenteiro de Roy Lourenço de Boa Memoria dayam que foi da dicta see e amostrou e perante o dicto cabidoo leer e publicar fez huum estormento escripto em purgaminho fecto e asiignado per maao de Lopo Dominguez tabelliam pollo dicto senhor Rei na cidade de Lixboa segundo em elle pareçia da qual o theor a tal he:

Sabham quantos este estormento de conhecimento virem que na Era de mil e quatrocentos e quareenta e dous annos viinte e nove do mes $\mathrm{d}$ Agosto dentro na claustra da egreja cathedral da cidade de Lixboa na capella em que os beneficiados da dicta egreja custumam fazer cabidoo, seendo hi os descretos barooes Gonçallo Dominguez chantre e procurador que se disse do Bispo de Silve e Gonçallo Anes thesoureiro e Domingos de Maguenta, Brãs Martinz, Joham Martinz, Garcia Martinz, Vasco Anes, Lourenço Gomez e Gonçallo Anes priol da Madanella coonigos na dicta egreja cathedral juntos no dicto cabidoo pera esto que se segue, presente mim Lopo Dominguez tabelliam d'El Rei na dicta cidade e testemunhas adeante escpritas Alvaro Martinz sobrinho de Roy Lourenço da Discreta memoria dayam que foy de Coinbra que outrosy estava presente, pos e preseitou na dicta cappela estes livros que se seguem:

Primeiramente huum boom Rosseyro ${ }^{(75)}$ que ja ante desto diserom que fora aballiado a triinta e cinque dobras.

[2] Item huum Codigo que foi abaliado a sete dobras.

[3] Item huum Degeesto novo que foi abaliado a oyto dobras.

[4] Item huum Esforçado que foi abaliado a oyto dobras.

[5] Item huum Degeesto velho que foi aballiado a sete dobras.

[6] Item huum Vollume sem Estatuta e sem tavoas aballiado a seis dobras.

[7] Item huuãs Decretaaes Bonhessas antigas que forom aballiadas a quinze dobras.

[8-11] Item huum ${ }^{(76)}$ Sexto com as grossas de Joham Monge. E Extravagantes de Bonifacio grosadas. E os textos das Crementiinas. E o Mandagoto aballiado a duas dobras.

[12] Item huum Soma de Groufedo aballiado a duas dobras.

[13-16] Item huum livro em que se contem o Mandagoto. E o livro Signodal da Egreja de Nemas e huum trautado de Gil de Fustoias. E o Digno sobre as Regas do Sexto aballiado todo a duas dobras.

(75) Talvez o Rosarium super Decretum, de Guydo de Basio, arcediago de Bolonha falecido em 1313. Vd. Isaías da Rosa Pereira, "Livros de Direito..", p. 50.

(76) Riscou: "sest". 
[17] Item huuã leitura sobre as Degretaaes e Ignota que tem huum G fremosso no começo e boas tavoas e boons prugaminhos aballiado a tres dobras.

[18-19] Item huum livro em que se contem primeiramente huum Trautado de Teollessia que se começa Inueste poderis e depois o Reportorio de Especullo em boa letera e em boom volume aballiado a ciinquo dobras.

[20-23] Item huum livro em que se contem Johanas de Blasciosto e as Difiniçooes de Lanberto de Salinis. E outro Trautado aballiado a duas dobras.

[24] Item Refredo Beneventano de Ordine Judiciario e sobre as auçõoes aballiado a huuã dobra.

[25] Item huuã Soma d'Aço aballiado a ciinquo dobras.

[26] Item huum livro das Eticas em boa letera e em boom vollume aballiado a duas dobras.

[27] Item huum Formullario em purgaminho com tavoas cubertas de coiro verde aballiado a tres dobras.

[28-34] Item huum livro de papel da marca grande em que se contem os Trautados de Bello e De Censura Ecclesiastica e de Sonyo e De Arborie Consanguinitate e De Amicitia et Pluralitate Beneficiorum e outros tractadinhos aballiado a dez dobras.

[35] Item outro livro de papel de marca grande em que se contem no começo, Comenta dominorum Johanis Caldeirini et domni Pauli de Lazaratis e outros tratados so as Decretaaes aballiado a dez e oyto ou dez e seis dobras.

[36] Item huum livro pequenino com tavoas que se começa na Robrica Sucepit liber Ysidorii Beati Episcopi.

[37] Item outro livro pequenino sem tavoas que se começa Quintus Nuçius.

[38] Item duas partes da Novella sobre as Decrataaes que diseram que som do douctor Martim do Sem.

[39] Item a Novella sobre o Sexto nom acabada em que a doze cadernos.

[40] Item huuã Extravagantes que se começa Benedictus.

[41] Item huã Lonbarda em purgaminho.

[42] Item huum caderno do officio de Sam Francisco em maa letera.

[43] Item huum Tractado sobre o Degeesto escripto em papel de marca grande. E começa sse In nomine Domini Nostri Ihesu Christi.

[44] Item doze cadernos de Breviairo de Sanctal.

[45] Item huum livro de papel em que falla dos tractados da emliçom do papa Urbano sobre a Çixma que nom era assiignado.

[46] Item huum caderno pequeno escripto em papel das Adiçooes do Inocencio. 
[47] Item outro caderno de Petiçooes de Leix escripto em papel.

[48] Item outro caderno escripto em papel que se começa Circa materiam.

[49] Item doze cadernos escriptos em papel sobre desvairadas cousas que nom eram assiignados.

[50] Item tres cadernos de papel dhuum Tractado De Bene Sucesio.

[51] Item huum livro pequeno que se começa Campanerius (?).

[52] Item huum livro pequeno de poetaria que se começa Frores Gramatice.

[53] Item outro livro pequeno que tem huuã tavoa de coyro e he Hordinhairo.

[54] Item outro livro pequeno que se começa Quintus Nucius.

[55] Item outro livro de Reprecaçooes sobre o Quinto livro do ${ }^{(77)}$ Degesto Velho.

[56] Item tres cadernos do Allano.

Os quaees livros como dicto he presentados e postos na dicta cappela, o dicto Alvaro Martinz disse que os dictos livros com outros livros que ja eram vendudos foram leixados pello dicto Roy Lourenço ao dicto cabidoo de Lixboa e aos cabudos de Coinbra e de Silve. E que elle fora requerido e constrangido que os trouvesse alli. E que porem requeria e requereo os dictos chantre e thesoureiro e coonigos que recebessem os dictos livros. $E$ lhe dessem huuã quitaçom ${ }^{(78)}$. E os dictos chantre thesoureiro e coonigos vista sua requesiçom em nome seu e dos dictos cabidos de Coinbra e de Silve receberam os dictos livros e se deram delles por emtregues. E derom o dicto Alvaro Martinz por quite e livre delles deste dia pera todo sempre. E o dicto Alvaro Martinz pedio de todo este estormento fecto e outorgado no logo dia mes e anno Era susodictos. Testemunhas que forom presentes Christove Anes vigairo e Gonçallo Rodriguez escripvam e Joham porteiro do dicto cabidoo e outros. E eu dicto Lopo Dominguez tabelliom que como dicto he a todo ${ }^{(79)}$ com as dictas testemunhas presente fui e este estormento escrepvi e aqui meu signal fiz que tal he.

O qual estormento de susso escripto asy mostrado pollo dicto Alvaro Martinz como dicto he os dictos chantre e cabidoo da See de Coinbra e come cabidoo e em seu nome e da dicta sua Egreja de Coinbra pediram

\footnotetext{
(77) Riscou: "deci".

(78) Palavra corrigida.

(79) Riscou: "poresent".
} 
delle o trallado pera guarda do seu direito e de poderem aver e cobrar a terça parte dos dictos livros pello dicto cabidoo de Lixboa a seu tempo e logo protestando aos pedir e demandar e cobrar pello dicto cabidoo de Lixboa e per outra qualquer pessoa que os tinha. E pedirom dello asy este estormento com o trellado do sobredicto estormento. E o dicto Alvaro Martinz lho mandou dar. Testemunhas que presente forom Alvaro Fernandez porteiro do dicto cabidoo e Gomez Lourenço amhoo d'El Rei e Joham Afomso da Estallagem e Gomez Lourenço que foi tabelliam moradores na dicta cidade $\mathbf{e}$ outros. E eu sobredicto tabelliam que este estormento escrepvi e aqui meu signal fiz que tal (sinal) he. 